\title{
Mineralogical and hydrogeological study of "pouhons" in the lower Palaeozoic formations of the Stavelot-Venn Massif, Belgium
}

\author{
Martin DEPRET ${ }^{1 *}$, YANnick BRUNI ${ }^{1}$, Alain DASSARGUES ${ }^{2}$, AgATHe DEFOURNY $^{2,3}$, JeAn-Marc MARION $^{4}$, \\ HYACINTHE-WILLY VANDERSCHUEREN ${ }^{5}$ \& FRÉDÉRIC HATERT ${ }^{1}$ \\ ${ }_{1}^{1}$ Laboratory of Mineralogy, Geology Department, University of Liège, Allée du Six-Août B18, 4000 Liège, Belgium. \\ ${ }^{2}$ Urban and Environmental Engineering, Applied Sciences Faculty, University of Liège, Allée de la Découverte 9, 4000 Liège, \\ Belgium. \\ ${ }^{3}$ Spadel S.A., Water resource department, Rue Auguste Laporte 34, B-4900 Spa, Belgium. \\ ${ }^{4}$ Evolution and Diversity Dynamics (EDDy) Lab, Geology Department, University of Liège, Allée du Six-Août B18, 4000 Liège, \\ Belgium. \\ ${ }^{5}$ Montefiore Institute, University of Liège, Allée de la Découverte 10, 4000 Liège, Belgium. \\ *corresponding author: martin.depret@uliege.be.
}

\begin{abstract}
Numerous naturally $\mathrm{CO}_{2}$-rich mineral water springs, locally called pouhons, occur in the Stavelot-Venn Massif. These water springs show a particular composition with a high content of iron, manganese and lithium, and are characterised by a redorange colour resulting from iron hydroxide precipitation near the land surface. Radon measurements have shown that these ferruginous deposits are weakly radioactive. The Upper Cambrian black shales of the La Gleize Formation are also known to display radioactive anomalies. These rocks show enrichment in HFSE ( $\mathrm{Pb}, \mathrm{U}, \mathrm{Y}, \mathrm{Ce}, \mathrm{Zr}, \mathrm{Ti}, \mathrm{Nb})$ and are depleted in transition metals (Co, Ni, $\mathrm{Cu}, \mathrm{Zn})$. Specific minerals such as florencite-(Ce), monazite-(Ce), xenotime-(Y) and zircon have been identified and are probably at the origin of the radioactive anomalies. Uranium was gradually leached from these minerals, transported in solution, and finally concentrated in ferruginous muds. These muds are mainly composed of goethite (most often amorphous), residual quartz and calcite in some samples. The most probable hypothesis is that uranium is adsorbed in small concentrations on the goethite surface. On the other hand, the Ottré Formation (Ordovician) appears to be the main source of lithium, iron and manganese. Pouhon waters have therefore probably leached rocks of various mineralogy and chemical composition during their sub-surface circulation.
\end{abstract}

KEYWORDS: Stavelot-Venn Massif, pouhon, black shales, uranium, ferruginous mud.

\section{Introduction}

Numerous naturally ferruginous and $\mathrm{CO}_{2}$-rich mineral water springs, locally called pouhons, occur in southeast Belgium. These water sources are mainly concentrated in the CambroOrdovician formations of the Stavelot-Venn Massif (SVM). Some are exploited, such as the mineral and thermal waters of Spa (Marie-Henriette) or the mineral waters of Bru-Chevron. These sources are also known for their curative properties and were first mentioned in journals (Naturalis Historiae) of Pliny the Elder (77-79 AD).

Although these water springs have been known and exploited for a long time, many questions remain as their age, their underground circulation pathway, the origins of the $\mathrm{CO}_{2}$ and their particular composition. Indeed, hydrogeological interpretations are relatively difficult in the SVM due to its complex geological setting. Pouhons are characterised by a redorange colour resulting from iron oxide and hydroxide precipitation linked to changing redox conditions near the surface. Radon measurements have shown that these ferruginous deposits are weakly radioactive (Vanderschueren, 2011). Uranium, at the origin of radon activity, was probably gradually leached from rocks, transported in solution, and finally concentrated in ferruginous muds. In this paper, we present a combined geological, mineralogical, geochemical, and hydrogeological study of pouhons; these data will improve our global understanding of these ferruginous springs.

\section{Geological setting}

The SVM, mainly located in Belgium (Fig. 1), is the largest and the best-studied Cambro-Ordovician inlier of the Ardenne Allochthon. It is part of the Rhenohercynian fold-and-thrust belt (Fielitz \& Mansy, 1999; Verniers et al., 2001) and is situated close to the Variscan front complex. The SVM has undergone a complex geodynamic history. It was affected by the Caledonian orogeny during the Ordovician and the Silurian, and by the Variscan orogeny at the end of the Carboniferous (Ziegler et al.,
1979; Cocks \& Fortey, 2009; Torsvik et al., 2012). The SVM was therefore severely deformed and fractured.

The SVM shows continuous terrigenous sedimentation (with minor volcanic episodes) from the lower Cambrian to the middle Ordovician for a total thickness of about $3000 \mathrm{~m}$ (Geukens, 1986, 1999; Verniers et al., 2001). It is subdivided into three lithostratigraphic units: the Deville, Revin, and Salm Groups (Geukens, 1986, 1999; Verniers et al., 2001; Herbosch et al., 2020).

The Deville Group (upper part of lower Cambrian) is subdivided into two formations: (1) The Hour Formation (old name: Dv1) which consists of greenish quartzites and green slates and (2) the Bellevaux Formation (Dv2) formed by an alternation of greenish to purplish slates and white quartzites (Geukens, 1986, 1999; Verniers et al., 2001).

The Revin Group (middle to upper Cambrian) is composed of three formations (Geukens, 1986, 1999; Verniers et al., 2001): (1) the Wanne Formation (Rv1-2) which consists of greenish to dark slates and greenish quartzites, (2) the Venne Formation (Rv3-4), consisting of heterogeneous alternations of dark slates and quartzites, and (3) the La Gleize Formation (Rv5) formed of siltites and black slates, sometimes graphitic. The term 'black shales' is the most appropriate to describe the fine-grained and laminated organic-rich sediments of this formation.

Finally, the Salm Group (lower to middle Ordovician) consists of three formations subdivided into eight members. (1) The Jalhay Formation (Sm1) comprises the Solwaster, Spa, and Lierneux members. This formation is formed of greenish to bluish slates, quartzites, and silty slates (locally called quartzophyllade). (2) The Ottré Formation ( $\mathrm{Sm} 2)$ includes the Meuville Member, the Les Plattes Member, in which coticule veins are found, and the Colanhan Member. This formation is mainly composed of red to purplish slates enriched in iron and manganese. (3) The Bihain Formation ( $\mathrm{Sm} 3$ ) includes the Ruisseau d'Oneux and Salmchâteau members. This formation is composed of dark silty slates (locally called quartzophyllade), and greyish quartzites (Geukens, 1986, 1999; Verniers et al., 2001).

https://doi.org/10.20341/gb.2021.001 
No sedimentation was recorded during the Silurian due to the Caledonian orogeny (Verniers et al., 2001). The SVM is directly surrounded by discordant conglomerates (Bultynck \& Dejonghe, 2001).

The SVM is divided into two metamorphic domains. The illite crystallinity and study of quartz veins in the basal conglomerates (Pridoli) have made it possible to identify an anchizonal Caledonian metamorphism (Spaeth et al., 1985; Kramm et al., 1985; Ferket et al., 1998). The conditions of this metamorphism were estimated between $180-280^{\circ} \mathrm{C}$ and $80-130$ $\mathrm{MPa}$ in the northern part of the Massif, and between $280-380{ }^{\circ} \mathrm{C}$ and $80-300 \mathrm{MPa}$ in the south (Ferket et al., 1998; Fielitz \& Mansy, 1999). The southern part of the SVM was also affected by Variscan greenschist-facies metamorphism (epizonal conditions) that superimposed and completely overprinted the Caledonian metamorphism in this area (Ferket et al., 1998; Fielitz \& Mansy, 1999). Conditions have been estimated between $320-450{ }^{\circ} \mathrm{C}$ and 100-300 MPa according to mineral assemblages (Schreyer, 1975; Kramm et al., 1985; Ferket et al., 1998; Fielitz \& Mansy, 1999). Some evidence of magmatic activity has also been identified in the SVM (Lamens \& Geukens, 1984).

\section{Uranium prospecting in Wallonia}

In 1852, André Dumont discovered some crystals of torbernite $\left(\mathrm{Cu}\left(\mathrm{UO}_{2}\right)_{2}\left(\mathrm{PO}_{4}\right)_{2} \cdot 12 \mathrm{H}_{2} \mathrm{O}\right)$ during an excursion in the Vielsalm region and was the first to record the occurrence of uraniumbearing minerals in the Ardennes (Dumont, 1852). However, it was not until after the Second World War that interest emerged in the radioactivity of the Belgian subsoil.

From 1955 to 1962, the Geological Survey of Belgium carried out a preliminary radiometric prospection using a portable scintillometer. Some radioactive anomalies have been identified in the SVM during this campaign. Most of them are located in the black shales of the La Gleize Formation (top of the Revin Group) with a radioactivity 4 to 5 times higher than the regional background (Charlet et al., 1983). Additional analyses by gamma spectrometry carried out by Charlet et al. (1977) indicated a relatively high uranium content (about 20 $\mathrm{ppm})$ and a low $\mathrm{Th} / \mathrm{U}$ ratio $(\sim 0.4)$ in these black shales.

Then, the Geological Survey of Belgium carried out a carborne prospection to measure uranium, thorium, and potassium contents in Wallonia subsoil. Again, they observed a series of anomalies whose spatial distribution seems to confirm the existence of a more radioactive level at the top of the Revin Group (Charlet et al., 1983).

Finally, in 1994 and 1995, the Geological Surveys of Belgium and Grand Duchy of Luxembourg carried out an airborne campaign. The aircraft followed a north-south trajectory spaced of one kilometre with measurements taken every second, i.e. approximately every 70 metres. Data were interpolated using a statistical kriging method to obtain a continuous spatial visualization (Vanderschueren et al., 2007). Results obtained show that the most uranium-rich areas are located along the Cambro-Ordovician limit, in the upper part of the La Gleize Formation (RV5) and the lower part of the Jalhay Formation (Solwaster Member). Both are composed of black shales which are probably at the origin of the high uranium contents. However, these formations have never been studied from a mineralogical point of view.

\section{Hydrogeology}

\subsection{Hydrogeological setting}

Two types of aquifer are known in the SVM: (1) Shallow aquifers related to differential alteration of the bedrock. The most interesting aquifer areas correspond to the alteration of quartzite whereas clay products resulting from slate alteration form zones of low permeability. (2) Deep aquifer zones distributed in the more quartzitic and fractured/faulted zones of the bedrock which probably fed $\mathrm{CO}_{2}$-rich mineral water springs (Monjoie 1995; Jobé, 2014).

Pouhons result from complex underground processes involving sequentially water infiltration, interactions with rocks, $\mathrm{CO}_{2}$ assimilation, upwelling and finally water emergence (Barros et al., 2021). However, their spatial distribution shows that they are not randomly located but that their location seems to be controlled by geological and geomorphological factors. First of all, pouhons are mainly located in the immediate vicinity of the tectonic structures mapped by F. Geukens in 1999 (Monjoie, 1995; Fig. 1). Geophysical profiles combining ERT (electrical resistivity tomography) and IP (induced polarization) methods were carried out above known uplift zones in the Ardennes region (Defourny et al., 2020). These profiles always show important contrasts in both electrical resistivity and chargeability relatively close to the vertical axis of pouhons (Defourny et al., 2020). Resistivity anomalies are interpreted as saturated fractures while chargeability anomalies are probably linked to iron oxides and hydroxides precipitation in the upper part of the aquifer (Defourny et al., 2020). Faults and fractures therefore probably act as preferential drains enabling the uplift of $\mathrm{CO}_{2}$-rich groundwater to the surface. Then, pouhons are generally located in valleys (Monjoie, 1995; Fig. 2A-B). Nearly $80 \%$ of pouhons are situated closer than 100 $\mathrm{m}$ from a river and at an altitude between 300 and $400 \mathrm{~m}$ (Fig. $2 \mathrm{~B})$. This is probably due to the hydrostatic pressure decrease in the valleys which would favour the release of $\mathrm{CO}_{2}$ and then the upwelling of water (Monjoie, 1995). Finally, we notice that pouhons located in the SVM are mainly concentrated in rocks of the Revin Group (Fig. 1).

\subsection{Hydrochemistry}

$\mathrm{CO}_{2}$-rich mineral water springs in the SVM generally show calco-magnesian bicarbonate hydrochemical facies (Fig. 3). The average chemical composition of pouhons is given in Table 1. They are naturally oversaturated in $\mathrm{CO}_{2}$ (up to $4 \mathrm{~g} / \mathrm{l}$ ). These high carbon dioxide contents imply a slightly to moderately acidic $\mathrm{pH}$ inducing a higher aggressiveness. However, waters are moderately mineralised as shown by the electrical conductivity. Pouhons show a particular composition with a high content of iron and manganese (Jobé, 2014; Table 1). They also frequently contain unusually high concentrations of lithium (Table 1). On the other hand, they are characterised by low content of nitrate indicating the absence of anthropogenic pollution. Relatively close springs can show significant hydrochemical variations due to the different pathways of waters through the complex network of fractures or due to the aquifer from which they originally came (Monjoie, 1995).

The ${ }^{18} \mathrm{O}-{ }^{2} \mathrm{H}$ analyses show that these waters are situated on the meteoric waters line, excluding a volcanic origin (Fig. 4AB). Isotopic signature suggests that pouhons are primarily fed by meteoric water (Barros et al., 2021). The origin of $\mathrm{CO}_{2}$ in pouhons is still unknown and seems relatively complex. According to Jobé (2014) and Barros et al. (2021), $\mathrm{CO}_{2}$ could result from a combination of various processes. Two hypotheses are generally advanced: (1) $\mathrm{CO}_{2}$ would be produced by dissolution of marine limestones and/or carbonate nodules according to this reaction: $\mathrm{CaCO}_{3}+2 \mathrm{H}^{+} \rightarrow \mathrm{Ca}^{2+}+\mathrm{CO}_{2}(\mathrm{~g})$. However, no carbonate rocks were found in the SVM. They may occur at depth below the Midi-Eifel overthrust suggesting that meteoric water should infiltrate at least $2 \mathrm{~km}$ (Barros et al., 2021). (2) $\mathrm{CO}_{2}$ would be of mantellic origin and produced by 


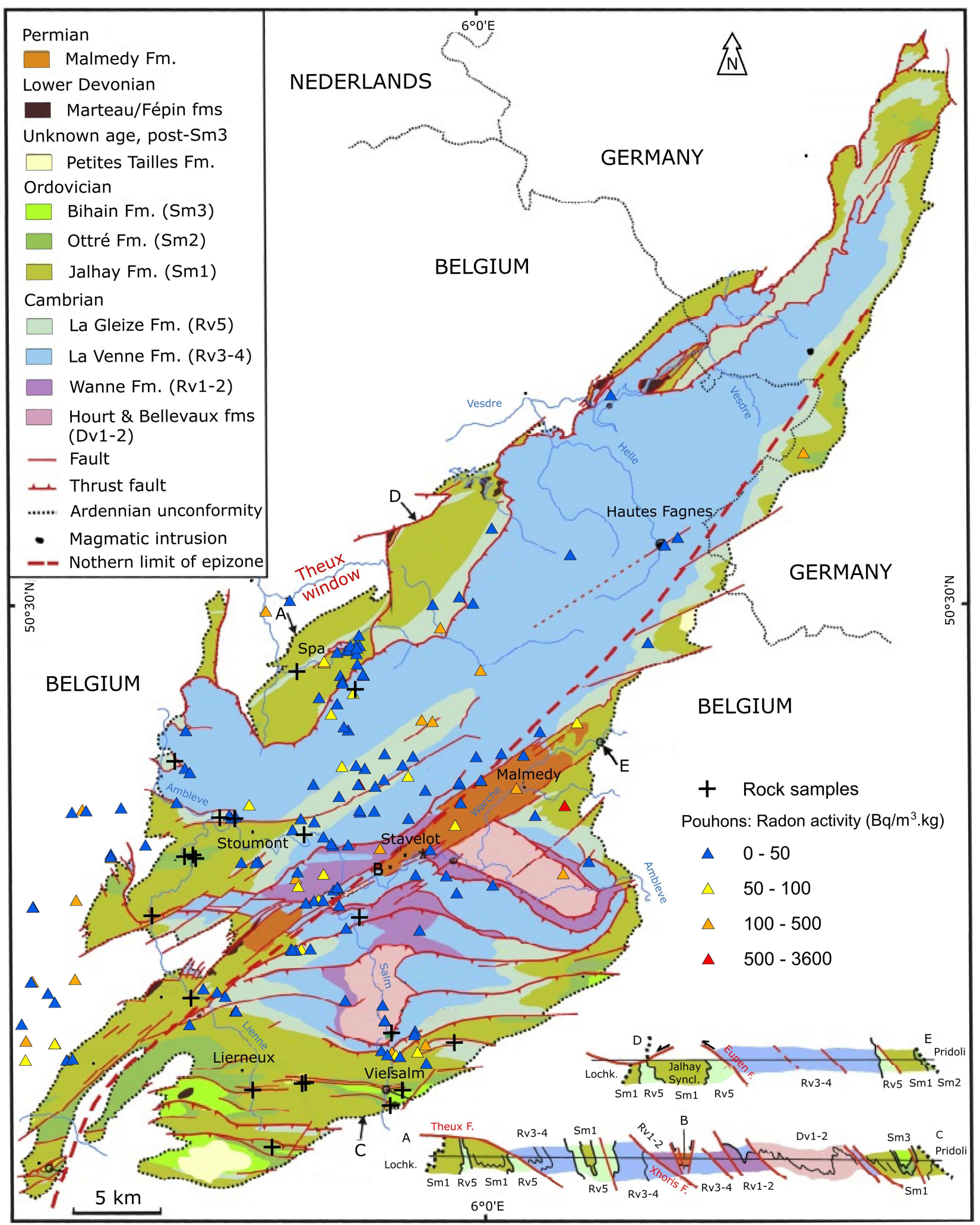

Figure 1. Location of analysed rock samples and pouhons in the SVM (modified after Geukens, 1999; Herbosch et al., 2020).

volcanic degassing related to the neighbouring Eifel area. The extension of the Eifelian mantle plume at depth or the presence of an unknown shallow magmatic reservoir under the SVM may then both constitute a potential source of $\mathrm{CO}_{2}$ (Barros et al., 2021).

Recent isotope analyses indicate that the $\delta^{13} \mathrm{C}$ of $\mathrm{CO}_{2}$ ranges from -9 to $-2 \%$ and up to $\sim 15 \%$ of $\mathrm{He}$ from magmatic origin has been identified in dissolved gases (Barros et al., 2021; Fig. 5). Therefore, it seems that $\mathrm{CO}_{2}$ shows a mixed origin, i.e. both carbonate and magmatic (Barros et al., 2021). The low temperatures of springs $\left(\sim 10{ }^{\circ} \mathrm{C}\right)$ and the presence of $\mathrm{CO}_{2}$ gas emanation on the surface (locally called "mofettes") suggest that $\mathrm{CO}_{2}$ probably rises from its source and is added to groundwaters at shallower depths (Barros et al., 2021).

\subsection{Radioactivity of pouhons}

The natural radioactivity of waters is directly related to the nature of rocks that they interact with during their underground 
A

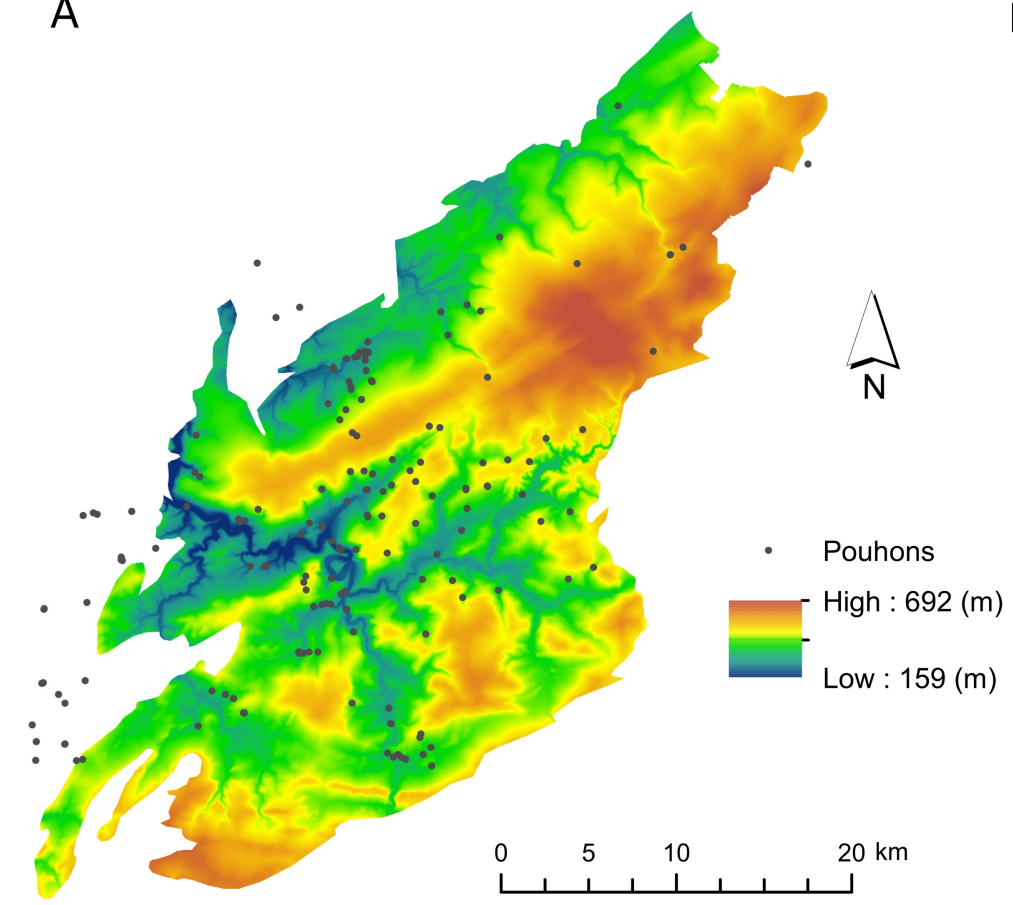

B

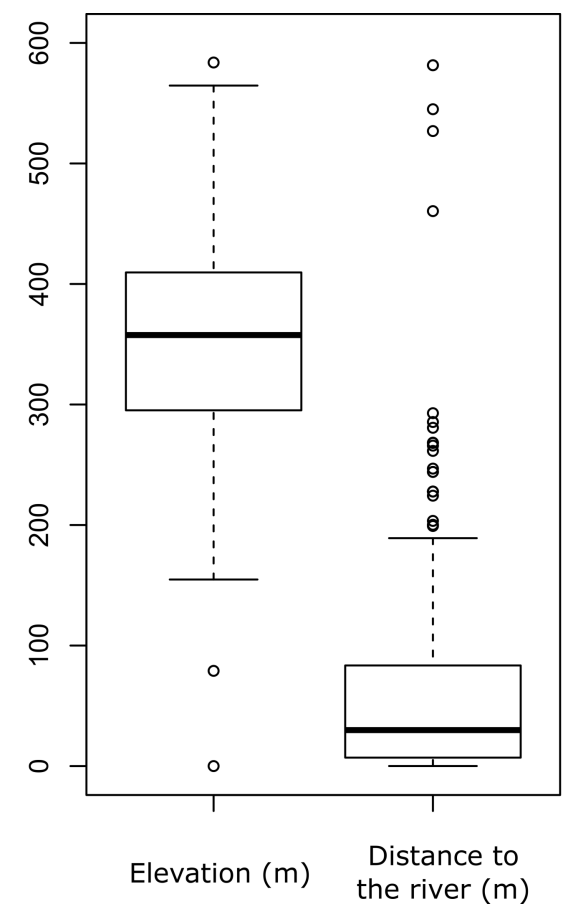

Figure 2. (A) Pouhon locations on the topographic map of the SVM. (B) Geostatistical data of pouhons.

circulation pathway. Most natural groundwaters contain radon produced by the disintegration of uranium. Measurements of radon activity in pouhon waters were carried out by Vanderschueren (2011). Most of them show moderate activity (10 to $100 \mathrm{~Bq} / \mathrm{l}$ ) with some exceptions which show higher radiation levels $(1220 \mathrm{~Bq} / \mathrm{l})$.

As mentioned before, pouhons show an orange-red colour linked to iron oxide and hydroxide precipitation. Iron is initially reduced to $\mathrm{Fe}^{2+}$ in conditions of $\mathrm{pH}$ (between 4 and 6) and $\mathrm{Eh}$ (between -0.3 and $+0.2 \mathrm{~V}$ ) prevailing at depth (Defourny et al., 2020). However, conditions become more oxidizing during groundwater upflows inducing rapid oxidation of $\mathrm{Fe}^{2+}$ to $\mathrm{Fe}^{3+}$ according to this reaction: $4 \mathrm{Fe}^{2+}+3 \mathrm{O}_{2}+2 \mathrm{H}_{2} \mathrm{O}=4 \mathrm{FeO}(\mathrm{OH})$. In addition, the release of $\mathrm{CO}_{2}$ close to the surface induces an increase in $\mathrm{pH}$ which can also lead to iron hydroxide formation. Radon measurements have shown that these ferruginous deposits are also weakly radioactive (Vanderschueren, 2011). Uranium at the origin of radon activity was therefore solubilised

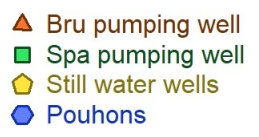

\section{Piper diagram}

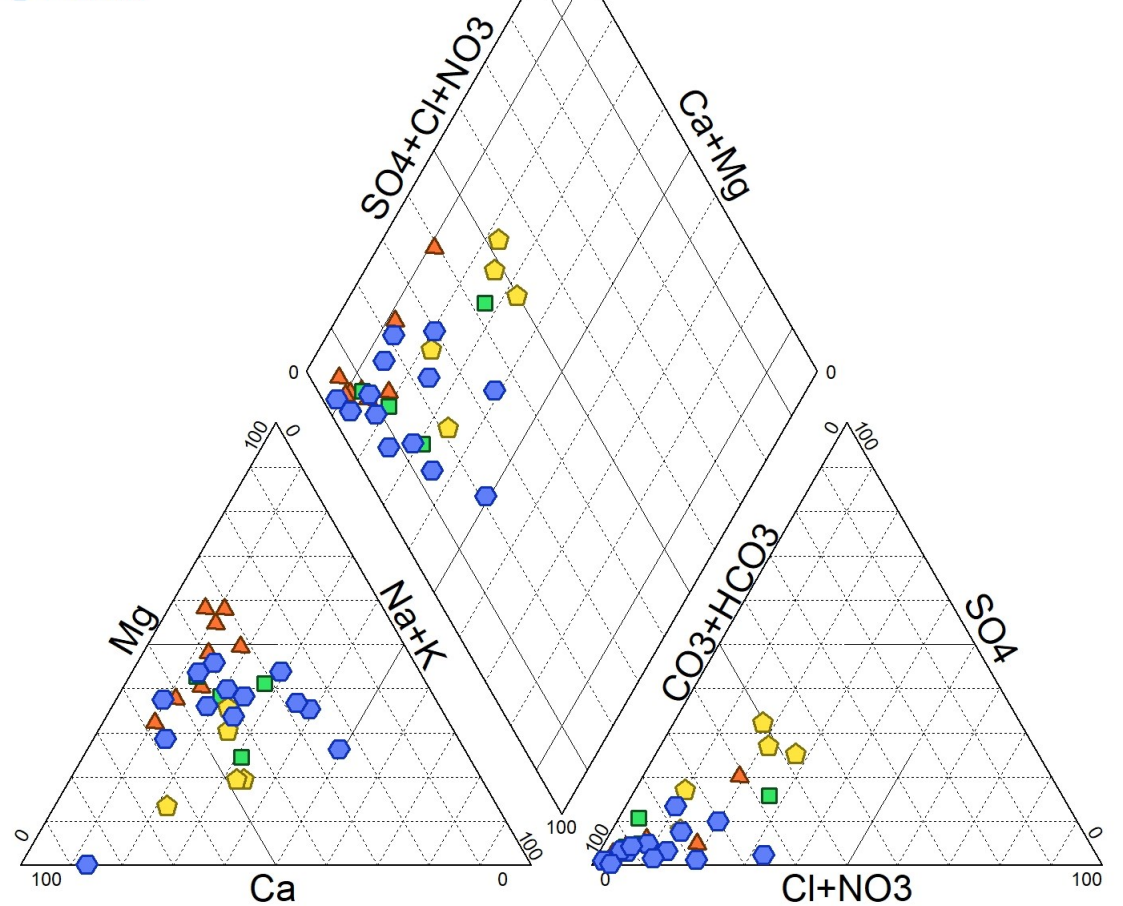

Figure 3. Piper diagram of pouhon waters. 


\begin{tabular}{lr}
\hline \multicolumn{2}{c}{$\begin{array}{c}\text { Average chemical } \\
\text { composition of pouhons }\end{array}$} \\
\hline $\mathrm{pH}$ & 5.70 \\
$\mathrm{EC}(\mu \mathrm{S} / \mathrm{cm})$ & 550.00 \\
$\mathrm{Ca}(\mathrm{mg} / \mathrm{l})$ & 43.30 \\
$\mathrm{Mg}(\mathrm{mg} / \mathrm{l})$ & 27.20 \\
$\mathrm{Na}(\mathrm{mg} / \mathrm{l})$ & 28.80 \\
$\mathrm{~K}(\mathrm{mg} / \mathrm{l})$ & 3.80 \\
$\mathrm{Cl}(\mathrm{mg} / \mathrm{l})$ & 17.60 \\
$\mathrm{SiO}_{2}(\mathrm{mg} / \mathrm{l})$ & 22.00 \\
$\mathrm{HCO}$ & $(\mathrm{mg} / \mathrm{l})$ \\
$\mathrm{Fe}(\mathrm{mg} / \mathrm{l})$ & 310.00 \\
$\mathrm{Mn}_{(\mathrm{mg} / \mathrm{l})}$ & 15.00 \\
$\mathrm{Li}(\mu \mathrm{g} / \mathrm{l})$ & 1.30 \\
$\mathrm{CO}_{2}(\mathrm{~g} / \mathrm{l})$ & 62.70 \\
\hline
\end{tabular}

Table 1. Average chemical composition of pouhons (Barros et al., 2021).

, 2021$)$

from an initial source, transported in solution probably under the form of $\mathrm{UO}_{2}{ }^{2+}$ and finally concentrated in ferruginous muds. It is necessary to characterise the mineralogy of these muds to determine which mineral phase carries the high uranium (or thorium) contents.

\section{Data collection and analyses}

Various rocks collected in the SVM and almost 200 samples of ferruginous muds analysed by H.W. Vanderschueren to measure their radon activity were available to characterise their mineralogy (Fig. 1; Fig. 6A-H). All these samples were milled to obtain a homogeneous powder and analysed from a mineralogical and geochemical point of view, with particular attention to black shales of the La Gleize Formation recognised as presenting radioactive anomalies.

Major oxides $\left(\mathrm{SiO}_{2}, \mathrm{Al}_{2} \mathrm{O}_{3}, \mathrm{TiO}_{2}, \mathrm{Fe}_{2} \mathrm{O}_{3 \text { tot }}, \mathrm{MnO}, \mathrm{MgO}\right.$, $\mathrm{CaO}, \mathrm{Na}_{2} \mathrm{O}, \mathrm{K}_{2} \mathrm{O}, \mathrm{P}_{2} \mathrm{O}_{5}$, LOI) and some trace elements $(\mathrm{Nb}, \mathrm{Y}$, $\mathrm{Zr}, \mathrm{Sr}, \mathrm{Rb}, \mathrm{U}, \mathrm{Th}, \mathrm{Pb}, \mathrm{Zn}, \mathrm{Ni}, \mathrm{Co}, \mathrm{Ga}, \mathrm{Ba}, \mathrm{Cr}, \mathrm{Ce})$ were obtained by X-ray fluorescence (XRF) with an ARL 9400XP spectrometer. Lithium borate fused glass discs were made to measure major elements while trace elements were analysed on pressed powder pellets. Matrix corrections were realised, and accuracy is estimated as better than $1 \%$ for major elements and

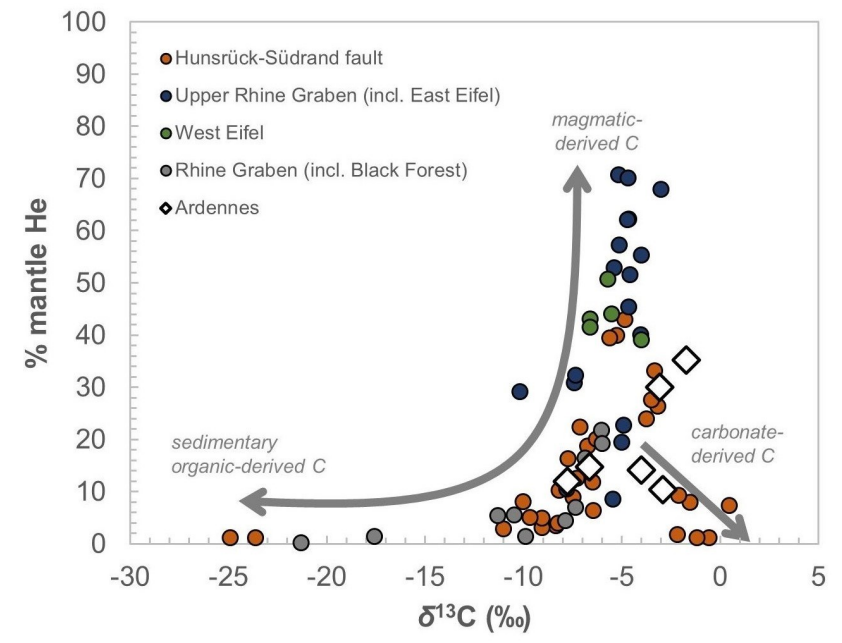

Figure 5. Variation of percentage mantle $\mathrm{He}$ and $\delta^{13} \mathrm{C}$ values for $\mathrm{CO}_{2}$ -rich groundwaters in Belgium (Ardennes) and Germany (Barros et al., 2021 after Griesshaber et al., 1992).

$5 \%$ for trace elements.

Mineralogical analyses were performed by powder X-ray diffraction (XRD) using a Bruker D8-ECO diffractometer (CuK $\alpha$ radiation, $\lambda 1.5418 \AA$ ). X-rays are filtered through a Ni filter to limit the $K \beta$ contribution. The goniometer covers a $2 \theta$ angle between 2 and $70^{\circ}$ with a step of $0.02^{\circ}$ and a counting time of 1 second per step. X-ray powder patterns were interpreted using the Bruker EVA 3.2 programme with the ICDD database (PDF-2 version). Quantification of mineral phases was performed by Rietveld refinement of the powder diffraction patterns, by using the Bruker TOPAS 4.2 programme. Chemical analyses have not been used to constrain the Rietveld refinements.

Qualitative chemical analyses were performed with a JCM6000 NeoscopeTM electron microprobe (Mineralogy Laboratory, Natural History Museum, Luxembourg) using an accelerating voltage of $15 \mathrm{kV}$ on polished section and ferruginous muds. EDX detector is an SDD of JEOL technology.

Infrared spectra were performed on ferruginous muds by a Thermo Nicolet NEXUS 470 FTIR spectrometer with a $1 \mathrm{~cm}^{-1}$ resolution, over the $400-4000 \mathrm{~cm}^{-1}$ range. The samples were prepared by mixing $2 \mathrm{mg}$ of a sample with $\mathrm{KBr}$ and compressed to form a pellet which was dried for a few hours at $110^{\circ} \mathrm{C}$.
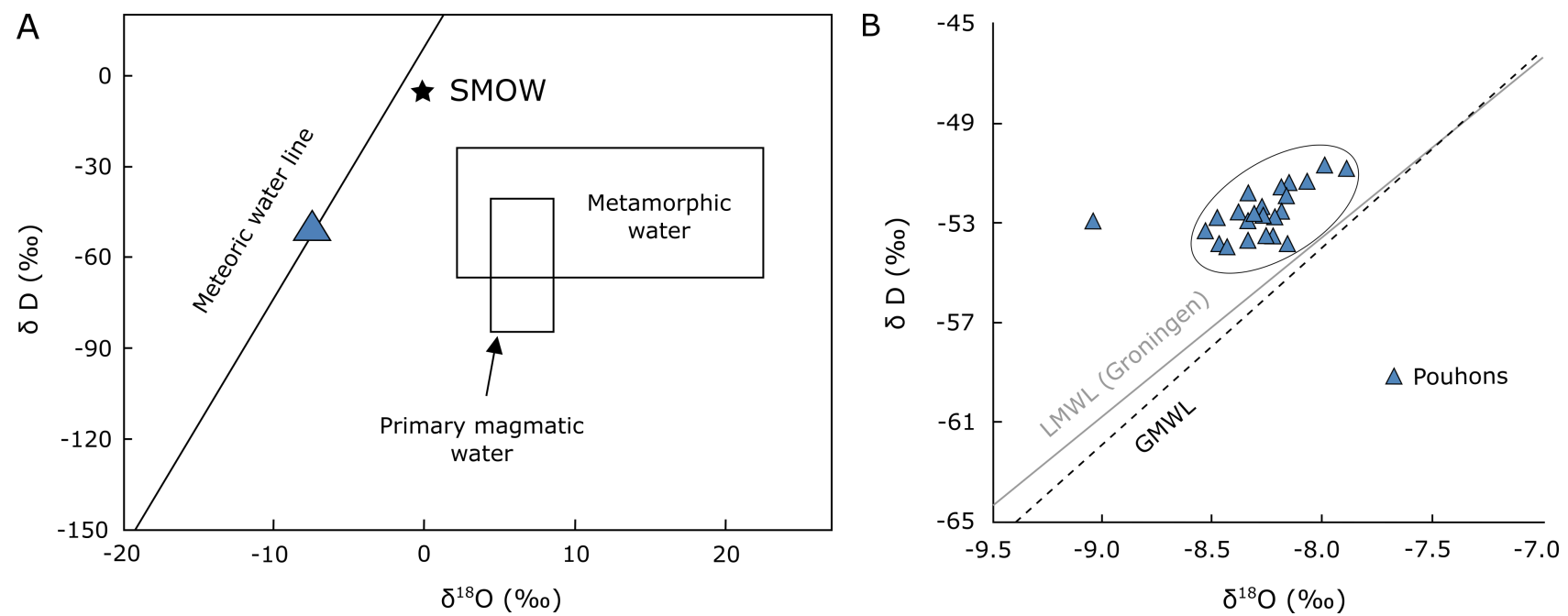

Figure 4. Available $\delta^{18} \mathrm{O}$ and $\delta \mathrm{D}$ data for pouhons (data: Defourny et al., 2019). (A) Global composition. The magmatic, metamorphic water boxes and meteoric water line are after Taylor (1974). (B) Global Meteoric Water Line (GMWL) after Rozanski et al. (1993). Data for the local meteoric water line (LMWL (Groningen)) after IAEA/WMO (2019). 

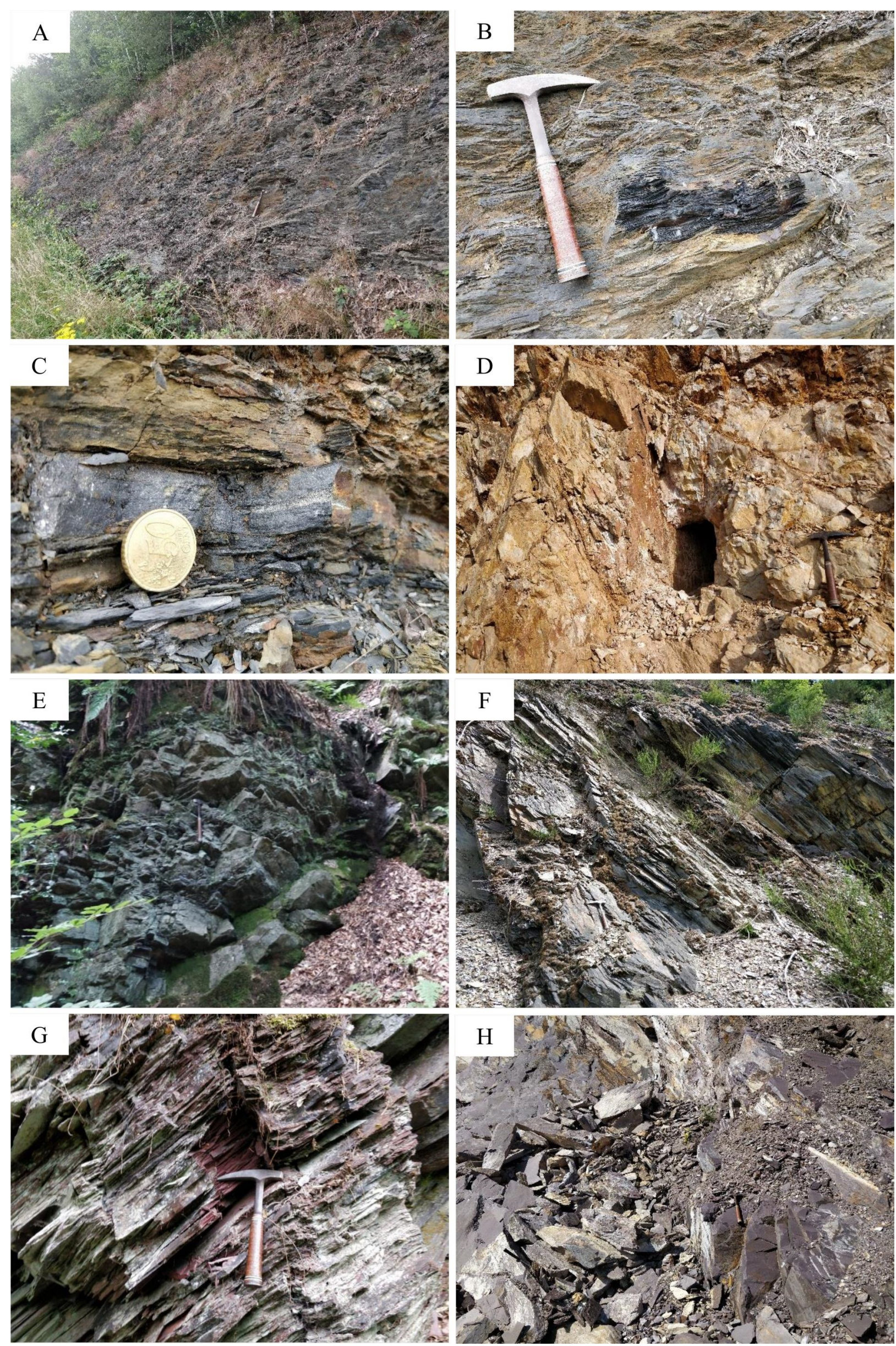

Figure 6. Various outcrops sampled in the SVM. (A) Black shales of the La Gleize Formation (Spa). (B) Detailed view of the outcrop. (C) A quarzitic layer enriched in pyrite in black shales of the La Gleize Formation (Spa). (D) Quartzites from the Deville Group (Hourt). (E) Quartzites of the Revin Group (Quarreux). (F) Black slates of La Venne Formation (Trois-Ponts). (G) Red slates of the Ottré Formation (Meuville). (H) Purplish slates and coticule of the Les Plattes Member (Thier del Preu). 


\section{Mineralogical and geochemical analyses}

\subsection{Black shales of the La Gleize Formation}

The black shales of the La Gleize Formation have a typical mineralogical composition. They are mainly composed of quartz $\left(\mathrm{SiO}_{2}\right)$, muscovite $\left(\mathrm{KAl}_{2}\left[\mathrm{Si}_{3} \mathrm{AlO}_{10}\right](\mathrm{OH})_{2}\right)$, chlorite $\left(\left(X_{5} \mathrm{Al}\right)\right.$ $\left[\mathrm{Si}_{3} \mathrm{AlO}_{10}\right](\mathrm{OH})_{8}$ with $X=\mathrm{Fe}, \mathrm{Mg}$ or $\left.\mathrm{Mn}\right)$, feldspar $\left(\left((\mathrm{Na}, \mathrm{K})_{1-}\right.\right.$ $\left.\left.{ }_{\mathrm{x}} \mathrm{Ca}_{\mathrm{x}}\right)\left[\left(\mathrm{Al}_{1+\mathrm{x}} \mathrm{Si}_{3-\mathrm{x}}\right) \mathrm{O}_{8}\right]\right)$ and minor pyrite $\left(\mathrm{FeS}_{2}\right)$ and rutile $\left(\mathrm{TiO}_{2}\right.$; Fig. 7A-B). Variations in mineralogical proportions are given in Table 2. Monazite-(Ce) $\left(\mathrm{CePO}_{4}\right)$ and zircon $\left(\mathrm{ZrSiO}_{4}\right)$ have also been detected by X-ray powder diffraction in some samples but their proportions are generally relatively low.

SEM analyses have made it possible to detect more specific minerals such as barite, florencite-(Ce), monazite-(Ce), xenotime-(Y), and zircon (Fig. $7 \mathrm{C}-\mathrm{H})$; these minerals are described below.

\subsubsection{Florencite-(Ce), $\mathrm{CeAl}_{3}\left(\mathrm{PO}_{4}\right)_{2}(\mathrm{OH})_{6}$}

Florencite-(Ce) has been identified in various samples, as irregular grains with diameters between 5 and $50 \mu \mathrm{m}$. They are generally associated with pyrite although isolated grains have also been observed (Fig. 7C). Semi-quantitative EDX analyses indicate that florencite mainly contains $\mathrm{Ce}, \mathrm{Al}$ and $\mathrm{P}$, with smaller amounts of $\mathrm{La}$ and $\mathrm{Nd}$.

\subsubsection{Monazite-(Ce), $\mathrm{Ce}\left(\mathrm{PO}_{4}\right)$}

Monazite-(Ce) is relatively abundant and was identified in most samples, as polygranular masses with a size ranging from 50 to $200 \mu \mathrm{m}$ (Fig. 7D-E). The EDX analyses show that these grains mainly contain $\mathrm{Ce}$ and $\mathrm{P}$, with smaller amounts of $\mathrm{La}$ and $\mathrm{Nd}$.

\subsubsection{Sphalerite, $(\mathrm{Zn}, \mathrm{Fe}) \mathrm{S}$}

Sphalerite grains are very small $(<10 \mu \mathrm{m})$ and always occur as inclusions in pyrite (Fig. 7F). Their EDX analyses show the presence of $\mathrm{Zn}$ and $\mathrm{S}$, with smaller amounts of $\mathrm{Fe}$ and $\mathrm{Cd}$.

\subsubsection{Xénotime-(Y), $\mathrm{YPO}_{4}$}

One grain of xenotime-(Y) has been identified in the Viel sample, as an isolated grain of very small size $(1-2 \mu \mathrm{m})$. The EDX analysis shows $\mathrm{Y}$ and $\mathrm{P}$ as main constituents, thus confirming the identification.

\subsubsection{Zircon, $\mathrm{Zr}\left(\mathrm{SiO}_{4}\right)$}

Zircon has been frequently identified as isolated crystals of variable size (10 to $80 \mu \mathrm{m})$. Some crystals are euhedral and well zoned (Fig. 7G-H), and some of these zonations are enriched in calcium, uranium, thorium, scandium and cerium.

Geochemical data are given in Table 2 and Table 3. The black shales of the La Gleize Formation mainly contain $\mathrm{SiO}_{2}$ and $\mathrm{Al}_{2} \mathrm{O}_{3}$, as well as $\mathrm{K}_{2} \mathrm{O}, \mathrm{MgO}$ and $\mathrm{Fe}_{2} \mathrm{O}_{3}$ in lower concentrations. The proportions of $\mathrm{TiO}_{2}, \mathrm{MnO}, \mathrm{CaO}, \mathrm{Na}_{2} \mathrm{O}$ and $\mathrm{P}_{2} \mathrm{O}_{5}$ generally do not exceed $1 \mathrm{wt} . \%$. Trace element contents are normalised to the upper continental crust (UCC, McLennan, 2001) and plotted in a semi-logarithmic diagram (Fig. 8A). These rocks are mainly enriched in $\mathrm{V}$ and high field strength elements (HFSE; $\mathrm{Pb}, \mathrm{U}, \mathrm{Y}, \mathrm{Ce}, \mathrm{Zr}, \mathrm{Ti}, \mathrm{Nb}$ ) except in $\mathrm{Th}$ and $\mathrm{Cr}$, and depleted in transition metals $(\mathrm{Co}, \mathrm{Ni}, \mathrm{Cu}, \mathrm{Zn})$ and $\mathrm{Sr}$. The $\mathrm{U}, \mathrm{V}, \mathrm{Ce}$ and $\mathrm{Ti}$ enrichments are the most pronounced, particularly in black graphitic shales (Viel).

A thin level strongly affected by weathering was observed and sampled (Spox) within the black shales of Spa (SP2 and SR2; N50.48802, E5.84391). It is mainly composed of goethite, quartz, muscovite, and chlorite. For this sample, major and trace elements are normalised to the protolith to determine the behaviour of these elements during weathering (Fig. 8B). It shows a significant enrichment in $\mathrm{P}_{2} \mathrm{O}_{5}$ and transition metals as well as a depletion in HFSE except for $\mathrm{Zr}$. Copper shows the highest enrichment, with an average content of $20.5 \mathrm{ppm}$ in slates and $366 \mathrm{ppm}$ in this sample (Table 3). Uranium previously enriched in the protolith was not detected in the Spox sample.

\subsection{Other formations of the SVM}

Rock samples collected in the other formations have only been studied by X-ray powder diffraction and XRF (Tables 2 and 3). The Hourt, La Venne and Jalhay formations show similar mineralogy and are mainly composed of quartz, muscovite, chlorite, feldspar and rutile (Table 2).

The Ottré Formation shows more various mineralogy (Table 2 ). The reddish to purplish colour of these rocks results from the occurrence of hematite $\left(\mathrm{Fe}_{2} \mathrm{O}_{3}\right)$. This mineral has been detected in all samples except in the coticule (Cot2). The Lienne valley ore (UXO) displays the highest proportion in hematite (33.45 wt.\%), whereas the average percentage of this mineral in the host red slates is around 8 wt.\%. Spessartine $\left(\mathrm{Mn}_{3} \mathrm{Al}_{2}\left(\mathrm{SiO}_{4}\right)_{3}\right)$ has been detected in the coticule (Cot2), the pseudocoticule (Pseu), the ore from the Lienne valley but also in the slates of Thier del Preu (Pcot1, Pcot2) and Salmchâteau (FCU). Spessartine does not exceed $10 \mathrm{wt} . \%$ in slates, whereas coticule and pseudocoticule show higher proportions of this mineral (13.86 wt.\% and 36.4 wt.\%, respectively). Chloritoid $\left(\left(\mathrm{Fe}^{2+}, \mathrm{Mg}, \mathrm{Mn}^{2+}\right) \mathrm{Al}_{2}\left(\mathrm{SiO}_{4}\right) \mathrm{O}(\mathrm{OH})_{2}\right)$ has been identified in the Lierneux slates (PAC) and in the slates of the Colanhan Member at Cahay (Cahp, Cahc). Finally, rhodochrosite $\left(\mathrm{MnCO}_{3}\right)$ has been identified in the Lienne valley manganese ore (UXO; 6.95 wt.\%), pyrolusite $\left(\mathrm{MnO}_{2} ; 2.10 \mathrm{wt} . \%\right)$ and zircon $(1.88 \mathrm{wt} . \%)$ in the Bihain slates (BMEU), and bornite $\left(\mathrm{Cu}_{5} \mathrm{FeS}_{4} ; 1.13 \%\right)$ in the Cahay slates (Cahp).

The formations occurring in the SVM show a relatively similar geochemical signature (Fig. 9A; Table 2). However, the Ottré Formation stands out and shows significant enrichments in $\mathrm{Fe}_{2} \mathrm{O}_{3}$ and $\mathrm{MnO}$ (Fig. 9A). The highest manganese contents are observed in the pseudocoticule $(\mathrm{Pseu}=15.65 \mathrm{wt} . \% \mathrm{MnO})$, the Lienne valley manganese ore $(\mathrm{UXO}=10.11 \mathrm{wt} \% \mathrm{MnO})$ and in the coticule $(\operatorname{Cot} 2=5.61$ wt. $\% \mathrm{MnO})$. The $\mathrm{CaO}$ and $\mathrm{P}_{2} \mathrm{O}_{5}$ contents also tend to increase in the Ottré Formation.

Trace element contents (Table 3) were once again normalised to the upper continental crust (UCC, McLennan, 2001), and plotted in a semi-logarithmic graph (Fig. 9B). The Hourt Formation is principally depleted in trace elements. The Jalhay and La Venne formations show a geochemical signature similar to that of the La Gleize Formation but are generally less enriched in trace elements, except in $\mathrm{Zn}, \mathrm{Ce}, \mathrm{Co}$ and Ni. The Ottré Formation is mainly enriched in $\mathrm{Ba}, \mathrm{Cr}$ and $\mathrm{Co}$, and depleted in U and Th. Finally, the Lienne ores, the coticule and the pseudocoticule show particularly high chromium contents of $676 \mathrm{ppm}, 1067 \mathrm{ppm}$ and $940 \mathrm{ppm}$, respectively.

A correlation matrix grouping majors and trace elements has been calculated (Fig. 10). Pearson coefficients show that $\mathrm{TiO}_{2}$ is relatively well correlated with $\mathrm{Al}_{2} \mathrm{O}_{3}$ and $\mathrm{K}_{2} \mathrm{O}$. CaO seems to be correlated with $\mathrm{MnO}$ and more particularly with $\mathrm{P}_{2} \mathrm{O}_{5}$. Strong correlations have been observed between $\mathrm{Ga}, \mathrm{Nb}, \mathrm{Rb}, \mathrm{TiO}_{2}$, $\mathrm{Al}_{2} \mathrm{O}_{3}, \mathrm{MgO}$ and $\mathrm{K}_{2} \mathrm{O}$. Co and $\mathrm{Cr}$ show a high correlation with $\mathrm{MnO}$. Uranium does not seem correlated with other elements, except vanadium $(0.82)$. 

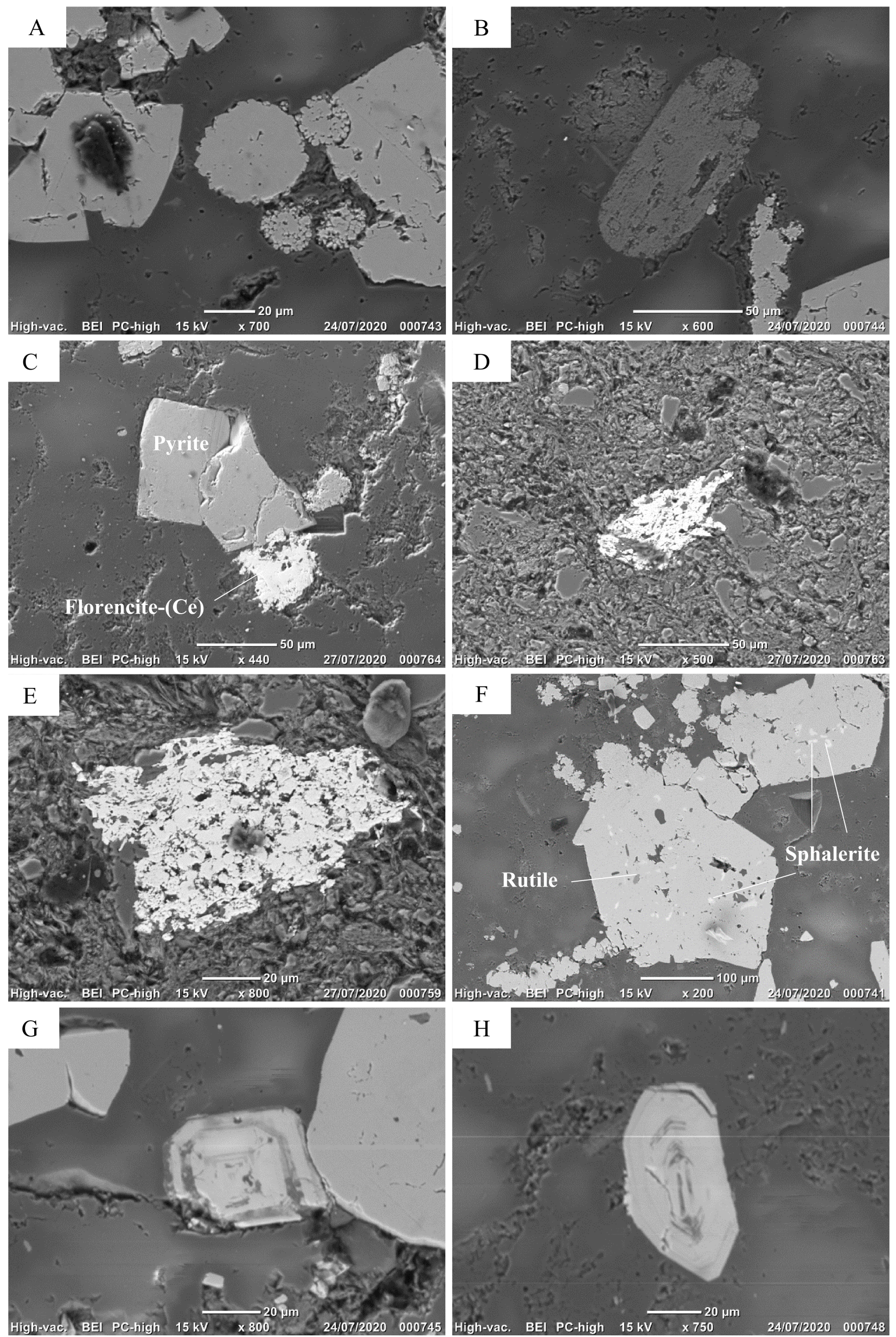

Figure 7. Scanning electron microscope (BSE) images of the Spa samples. (A) Euhedral and framboidal pyrite. (B) Elongated rutile. (C) Florencite(Ce) associated with pyrite. (D-E) Polygranular mass of monazite. (F) Inclusion of sphalerite (white) and rutile (grey) in pyrite. (G-H) Euhedral and well-zoned zircon. 
$\sum_{3}^{\infty}$

离

突芒芒

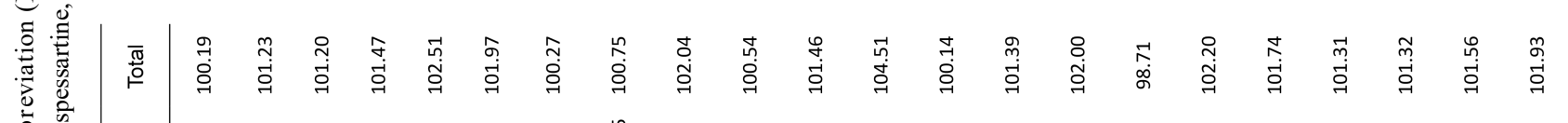

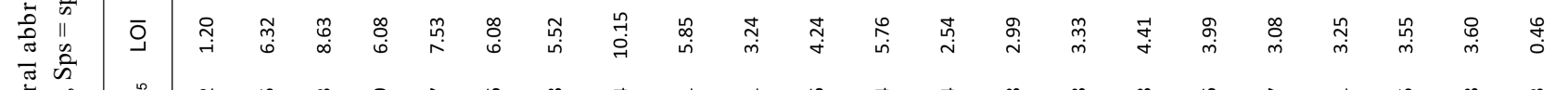

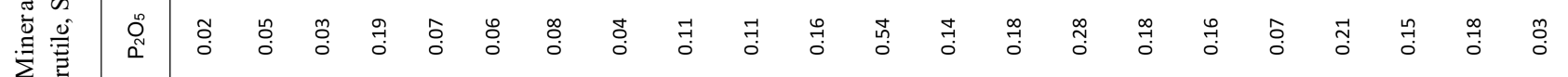

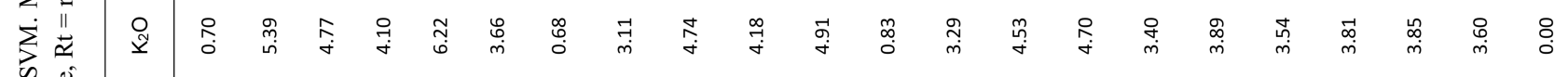
旁惫 的

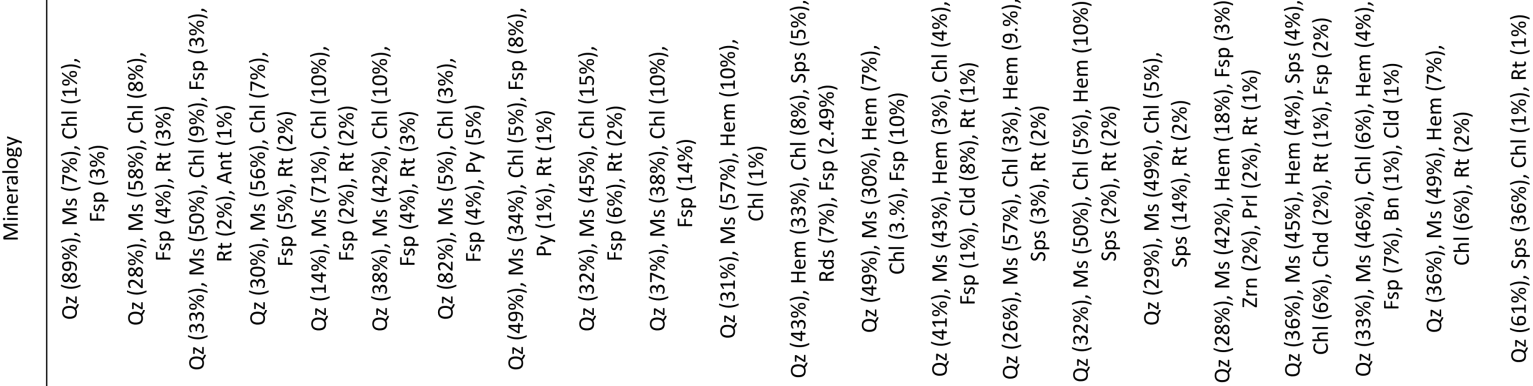

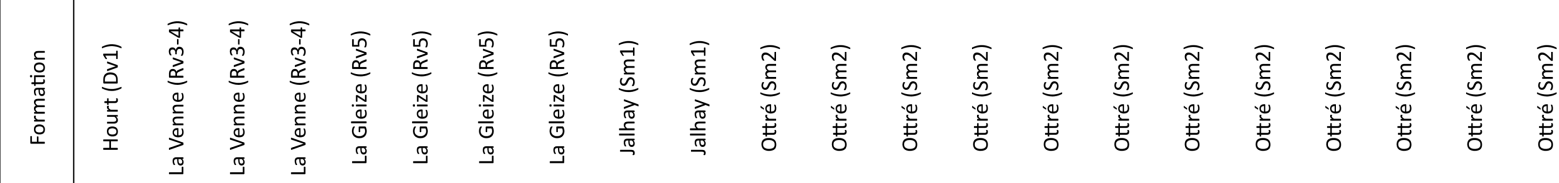


Table 3. Trace elements (ppm) geochemical XRF analyses of the rock samples collected in the SVM.

\begin{tabular}{|c|c|c|c|c|c|c|c|c|c|c|c|c|c|c|c|c|c|}
\hline Samples & Co & $\mathrm{Cu}$ & $\mathrm{Ga}$ & $\mathrm{Nb}$ & $\mathrm{Ni}$ & $\mathrm{Pb}$ & $\mathrm{Rb}$ & $\mathrm{Sr}$ & Th & $U$ & $Y$ & $\mathrm{Zn}$ & $\mathrm{Zr}$ & $\mathrm{Ba}$ & $\mathrm{Ce}$ & $\mathrm{Cr}$ & V \\
\hline SP2 & 6 & 27 & 5 & 11 & 20 & 15 & 38 & 68 & ND & 7 & 33 & 37 & 235 & 268 & 79 & 11 & 78 \\
\hline SR2 & 8 & 14 & 22 & 20 & 26 & 32 & 135 & 102 & 7 & 19 & 39 & 34 & 275 & 652 & 132 & 47 & 517 \\
\hline Viel & 6 & 30 & 35 & 27 & 8 & 19 & 246 & 166 & 11 & 20 & 44 & 72 & 225 & 1158 & 213 & 98 & 451 \\
\hline Venne & 8 & 26 & 25 & 20 & 20 & 18 & 156 & 119 & 3 & 6 & 33 & 81 & 192 & 642 & 111 & 68 & 170 \\
\hline Spox & 34 & 366 & 2 & 6 & 85 & 8 & 81 & 145 & ND & ND & 16 & 146 & 425 & 225 & 52 & 30 & 268 \\
\hline DEV & 4 & ND & 7 & 12 & ND & 33 & 32 & 43 & ND & 7 & 14 & 6 & 210 & 335 & 86 & 10 & 23 \\
\hline ETU & 5 & 17 & 31 & 23 & 11 & 8 & 213 & 120 & 7 & 6 & 38 & 45 & 215 & 862 & 186 & 84 & 165 \\
\hline $3 P$ & 5 & 25 & 27 & 24 & 13 & 16 & 191 & 91 & 8 & 8 & 43 & 60 & 211 & 825 & 185 & 63 & 232 \\
\hline $\mathrm{PZ2}$ & 19 & 28 & 27 & 23 & 42 & 21 & 163 & 125 & 11 & 3 & 43 & 80 & 255 & 794 & 213 & 82 & 137 \\
\hline PG & 14 & 22 & 27 & 23 & 37 & 10 & 178 & 106 & 6 & 3 & 32 & 92 & 185 & 1103 & 185 & 87 & 133 \\
\hline PGC & 15 & 17 & 21 & 20 & 29 & 12 & 161 & 96 & 6 & 3 & 33 & 99 & 223 & 1137 & 172 & 66 & 109 \\
\hline RSAL & 41 & 5 & 24 & 19 & 55 & 38 & 196 & 226 & 1 & ND & 21 & 92 & 132 & 1751 & 151 & 191 & 86 \\
\hline UXO & 149 & 28 & ND & 9 & 84 & 87 & 41 & 61 & ND & ND & 37 & 210 & 187 & 635 & ND & 676 & 207 \\
\hline MnM1 & 20 & 5 & 16 & 19 & 30 & 28 & 135 & 107 & 17 & 2 & 34 & 62 & 780 & 1002 & 170 & 96 & 97 \\
\hline PAC & 22 & 33 & 22 & 20 & 31 & 6 & 167 & 91 & 2 & 1 & 34 & 54 & 205 & 1342 & 155 & 90 & 98 \\
\hline Pcot1 & 56 & 7 & 23 & 19 & 84 & 47 & 194 & 344 & ND & ND & 37 & 81 & 155 & 1679 & 105 & 253 & 129 \\
\hline Pcot2 & 31 & 22 & 25 & 19 & 56 & 31 & 155 & 250 & 1 & ND & 30 & 89 & 126 & 1007 & 126 & 202 & 130 \\
\hline Cot2 & 33 & 16 & 28 & 22 & 47 & 35 & 169 & 275 & 6 & 1 & 43 & 109 & 140 & 1738 & $N D$ & 1067 & 167 \\
\hline BMEU & 50 & 49 & 17 & 15 & 18 & 54 & 166 & 385 & ND & ND & 45 & 37 & 124 & 848 & 49 & 295 & 158 \\
\hline FCU & 52 & 173 & 25 & 20 & 83 & 20 & 137 & 135 & 1 & ND & 36 & 97 & 154 & 2830 & 45 & 395 & 141 \\
\hline CahP & 33 & 15 & 27 & 21 & 55 & 31 & 175 & 235 & 3 & ND & 32 & 105 & 147 & 931 & 126 & 150 & 144 \\
\hline Cahc & 41 & 16 & 25 & 20 & 64 & 31 & 166 & 239 & ND & ND & 33 & 107 & 130 & 1130 & 112 & 205 & 163 \\
\hline PSEU & 11 & 29 & 2 & 10 & 5 & ND & 8 & 30 & ND & ND & 15 & 19 & 91 & 295 & ND & 940 & 319 \\
\hline
\end{tabular}

\subsection{Ferruginous muds}

Mineralogical analyses have been performed on ferruginous mud samples. X-ray powder patterns are generally marked by the presence of two very large peaks, located around $2 \theta$ values of $35^{\circ}$ and $63^{\circ}$. This shows the extremely poor crystallinity and probably the amorphous nature of muds. However, some X-ray powder patterns show better crystallinity. Goethite is the most frequently identified mineral, but quartz, calcite and dolomite have also been detected in some samples. Infrared spectra were also performed, showing absorption bands that coincide fairly well with those of goethite $(3300,1800,1000,890,795$ and $595,470 \mathrm{~cm}^{-1}$ ), indicating once again that these muds are mainly composed of this mineral (Fig. 11). Other well-marked bands have been observed, showing that muds contain other phases. The $1495 \mathrm{~cm}^{-1}$ band is certainly produced by vibrations of carbonate groups, while the band at $1630 \mathrm{~cm}^{-1}$ corresponds to the deformation vibrations of the water molecule (Kodama, 1985). The $1365 \mathrm{~cm}^{-1}$ peak is probably associated with the vibrations of nitrate groups (Kodama, 1985).

From a geochemical point of view (Table 4), these muds are mainly composed of $\mathrm{Fe}_{2} \mathrm{O}_{3}( \pm 65$ wt.\%), as well as smaller proportions of $\mathrm{SiO}_{2}( \pm 3.86$ wt. $\%)$ and $\mathrm{P}_{2} \mathrm{O}_{5}( \pm 3.78$ wt. \%). Loss on ignition (LOI) is relatively high indicating a significant loss in volatiles. Sampling conditions did not systematically allow the collection of pure ferruginous deposits. Contaminations are noticeable in GER, PIL and SAUV samples with a significant increase of the silica contents compared to $\mathrm{Fe}_{2} \mathrm{O}_{3}$. Regarding trace elements, muds are mainly enriched in $\mathrm{Sr}, \mathrm{Ba}, \mathrm{Ce}, \mathrm{Zr}, \mathrm{Cu}$ and $\mathrm{Zn}$ (Fig. 12; Table 4). The RUY sample shows the highest zirconium content (1843 ppm), and the BAR sample shows a relatively high zinc level (847 ppm). Uranium and thorium were not detected.

Images obtained with a scanning electron microscope show that grains in the muds are formed by an agglomeration of spheroids ( $1 \mu \mathrm{m}$ diameter) comparable to spherulites. An EDX elemental mapping has also been performed, which clearly shows that the muds are mainly composed of iron with some areas enriched in $\mathrm{Si}, \mathrm{Al}$ and $\mathrm{Ca}$. Some tiny spots of uranium have also been detected.

\section{Discussion}

\subsection{Origin of uranium in the black shales of the La Gleize Formation}

Black shales of the La Gleize Formation show classical mineralogy since they are mainly composed of quartz, muscovite, chlorite, feldspars, with variable quantities of pyrite and rutile (Table 2). More specific minerals, such as florencite(Ce), monazite-(Ce), xenotime-(Y), and zircon, have also been identified by SEM analyses. It is interesting to note that alluvial monazite-(Ce) was previously observed by Burnotte et al. (1989), in rivers cross-cutting the slates of the Revin Group in the SVM.

The ionic radius of $\mathrm{Ce}^{3+}\left(1.01 \AA\right.$; Shannon, 1976) and $\mathrm{Y}^{3+}$ $(0.90 \AA)$ are relatively close to that of $\mathrm{U}^{4+}(0.89 \AA)$. Uranium can consequently be incorporated into the crystallographic site of cerium or yttrium by coupled heterovalent substitutions with calcium at a single site, without affecting the mineral structure $\left(\mathrm{Ce}^{3+} \rightarrow 0.5 \mathrm{Ca}^{2+}+0.5 \mathrm{U}^{4+}\right)$. This substitution explains the occurrence of Th and $U$ in many rare-earth minerals such as florencite-(Ce), monazite-(Ce) or xenotime-(Y). $\mathrm{U}^{4+}$ can also be incorporated in the crystal structure of zircon by homovalent substitution with $\mathrm{Zr}^{4+}$ at a single site (Meis \& Gale, 1998), and rutile may also insert some uranium, probably by homovalent substitutions with $\mathrm{Ti}^{4+}$ (Mezger et al., 1989). All these minerals may incorporate small quantities of uranium into their structure and are therefore probably at the origin of the radioactive anomalies observed in these black shales. Uranium was likely gradually leached from these minerals, transported in solution, and finally concentrated in ferruginous muds.

From a geochemical point of view, these black shales are mainly enriched in V and HFSE ( $\mathrm{Pb}, \mathrm{U}, \mathrm{Y}, \mathrm{Ce}, \mathrm{Zr}$, Ti, Nb; Fig. 8A). Uranium, cerium and vanadium display the highest enrichments observed in the SVM, although uranium contents 
A

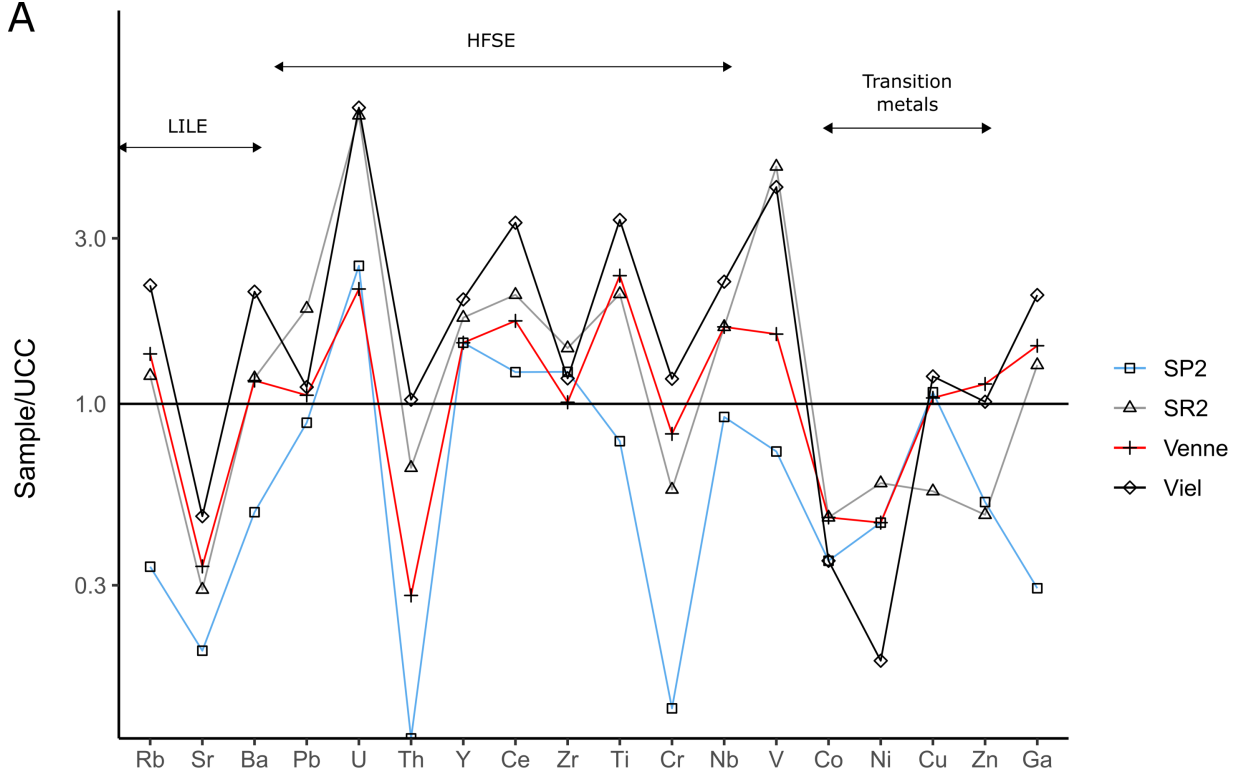

B

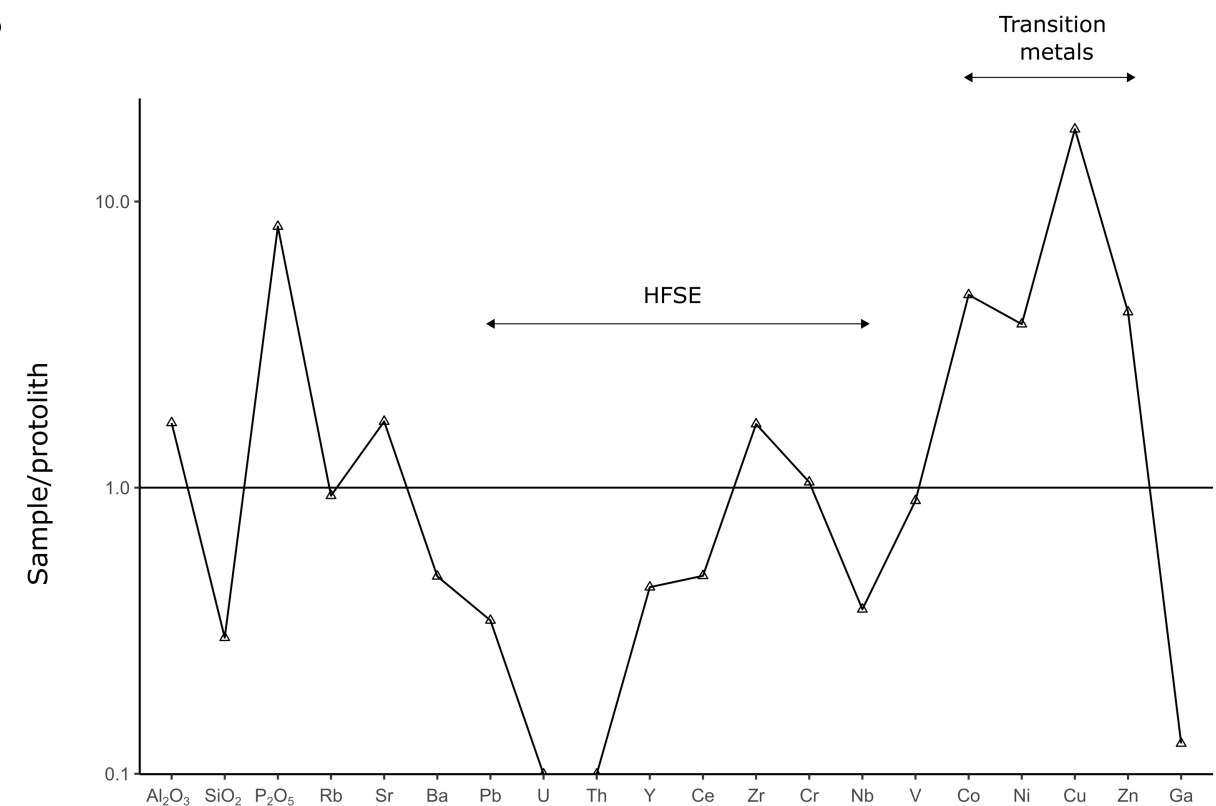

Figure 8. Trace element patterns of the black shales of the La Gleize Formation (A). Trace element contents normalised to the upper continental crust (McLennan, 2001). (B) Trace element pattern of Spox sample normalised to the protolith. are relatively low and do not exceed $20 \mathrm{ppm}$. It is noteworthy that $\mathrm{Ce}$ and $\mathrm{Y}$ contents, reaching around 200 and $40 \mathrm{ppm}$ respectively (Table 3), are similar to those reported by Burnotte et al. (1989) for the black slates of the Revin Group from La Vecquée and Grand-Halleux. On the other hand, these rocks are depleted in transition metals $(\mathrm{Co}, \mathrm{Ni}, \mathrm{Cu}, \mathrm{Zn})$ and in $\mathrm{Sr}$ (Fig. 8A).

Such low trace element contents are unusual in these types of rocks. Black shales are generally enriched in numerous redox -sensitive metals $(\mathrm{V}, \mathrm{Cr}, \mathrm{Ni}, \mathrm{U}, \mathrm{Co} \mathrm{Cu}, \mathrm{Zn})$ due to the conditions prevailing in their formation environment (Vine \& Tourtelot, 1970). The enrichment was probably inhibited in our samples by the unavailability of metals in the water column or by a high sedimentation rate inducing a high clastic dilution. The black graphitic shales of Vielsalm (Viel) show the most significant enrichments. Trace element contents in these rocks are therefore probably controlled by the organic matter and/or by the clay material contents.

\subsection{Geochemistry of the Ottré Formation and correlations}

The Ottré Formation is characterised by a significant enrichment in $\mathrm{Fe}_{2} \mathrm{O}_{3}, \mathrm{MnO}, \mathrm{Cr}$ and $\mathrm{Co}$, compared to the other rocks of the SVM (Fig. 9 A-B). The $\mathrm{Fe}_{2} \mathrm{O}_{3}$ enrichment results from the occurrence of hematite, whereas the $\mathrm{MnO}$ enrichment is directly related to the occurrence of spessartine and rhodochrosite These geochemical features are well known in the SVM, and were already described in several papers dealing with the geochemistry of coticules and pseudocoticules (Krosse \& Schreyer, 1993; Baijot et al. 2011; Herbosch et al., 2016). Uranium was not detected by XRF in these rocks.

Some correlations have been observed between major and trace elements (Fig. 10). Titanium and aluminium are both highly immobile, and the strong correlation between these elements probably results from their similar geochemical behaviour. The correlation between calcium and phosphorus is certainly due to the presence of accessory fluorapatite in these rocks (Hatert et al., 2002), as well as to the incorporation of calcium in the structure of cerium phosphate minerals. It is noteworthy that monazite-(Ce), florencite-(Ce), and xenotime$(\mathrm{Y})$ were yet known to occur in the slates of the Ottré Formation at Salmchâteau (Hatert et al., 2002; Blondieau et al., 2017). The correlation between $\mathrm{TiO}_{2}$ and $\mathrm{Nb}$ can be explained by the ability of rutile to incorporate niobium into its crystal structure. Indeed, 


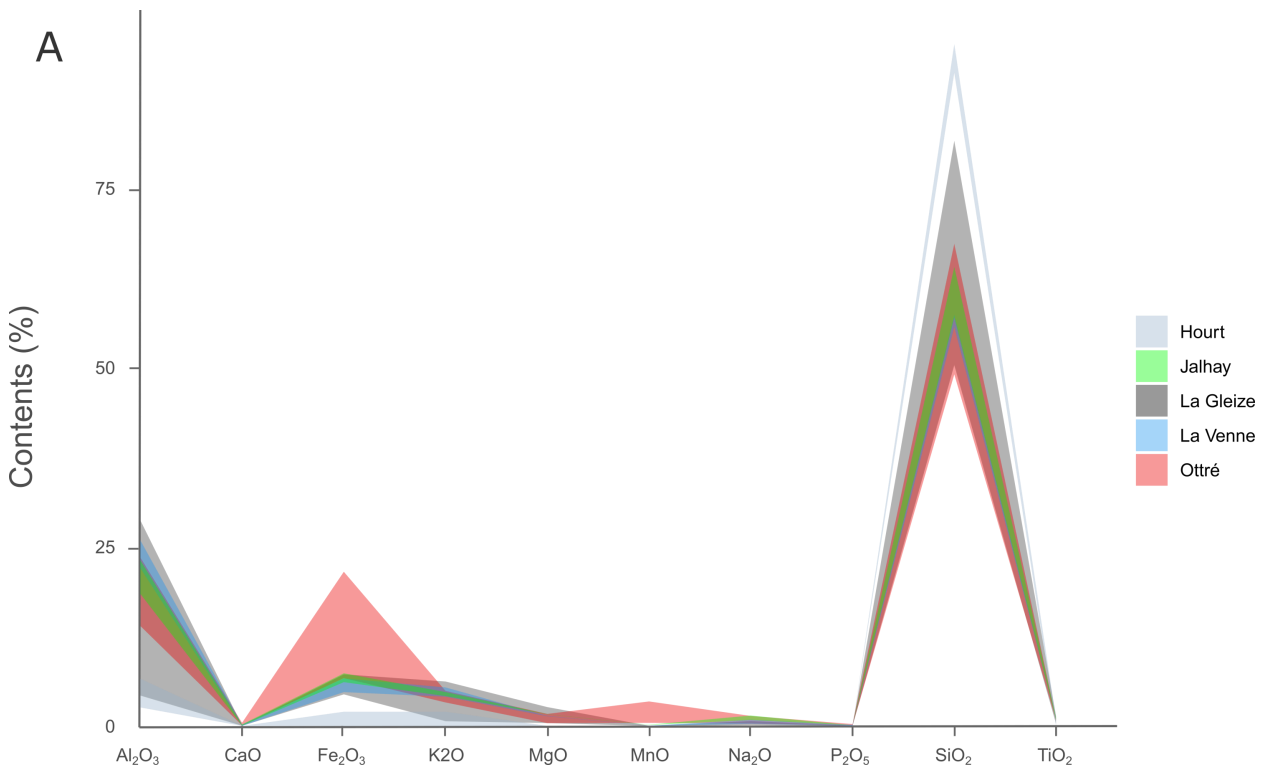

Figure 9. (A) Major element patterns from the rocks of the Hourt, Jalhay, La Gleize, La Venne and Ottré formations. (B) Trace element patterns from the rocks of the Hourt, Jalhay, La Gleize, La Venne and Ottré formations. The red line shows the average composition of the Ottré Formation.

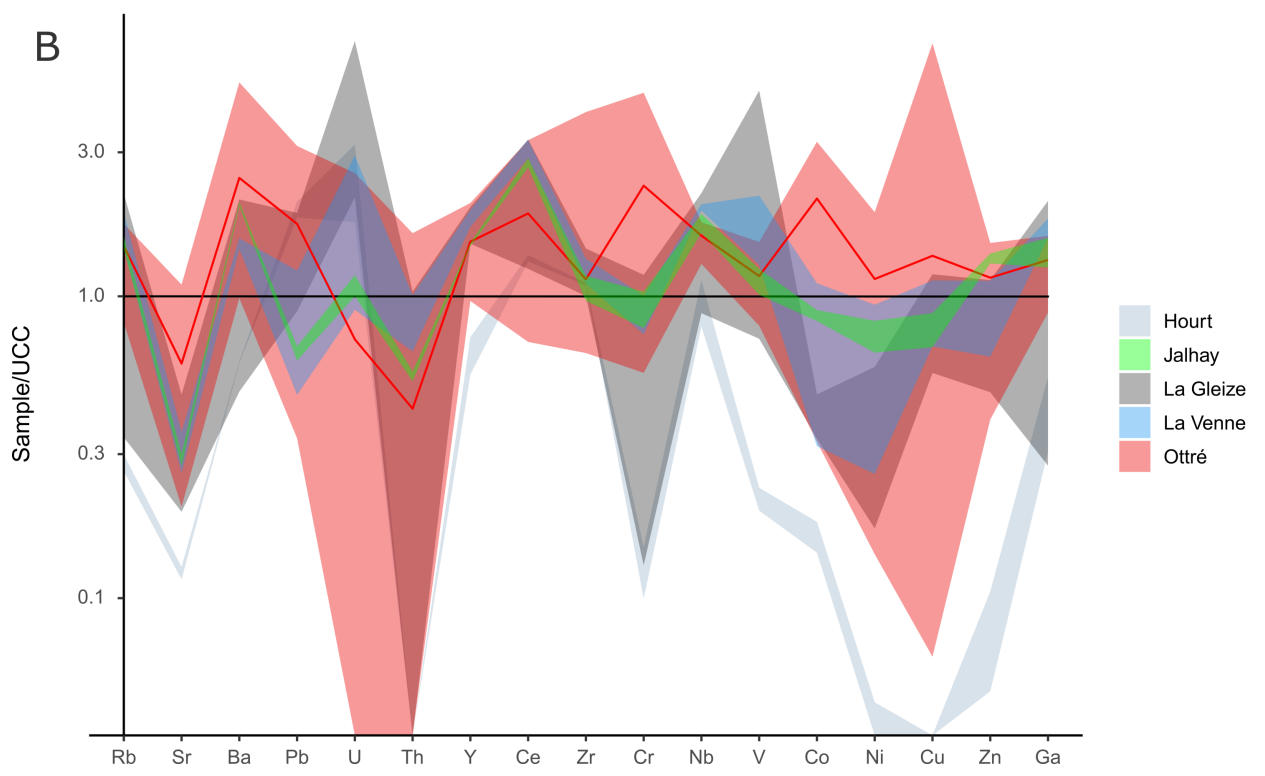

$\mathrm{Nb}^{5+}$ may substitute to $\mathrm{Ti}^{4+}$ in rutile, the excess charge is then compensated by metal vacancies or by a complementary amount of $\mathrm{Fe}^{2+}$ (Deer et al., 1962; Graham \& Morris, 1973). Gallium and rubidium are particularly well correlated with $\mathrm{Al}_{2} \mathrm{O}_{3}$ and $\mathrm{K}_{2} \mathrm{O}$; these elements are therefore probably associated with muscovite. The correlation between chromium, cobalt and manganese is not well understood. $\mathrm{Cr}$ could substitute to $\mathrm{Al}$ in spessartine thus explaining the strong correlation between $\mathrm{Cr}$ and $\mathrm{Mn}$.

\subsection{Composition and origin of ferruginous muds}

Ferruginous muds are mainly composed of goethite (most often amorphous), residual quartz, calcite, and dolomite in some samples. This assemblage suggests that iron initially dissolved in water precipitates essentially as goethite during groundwater upflow. Calcite and dolomite could precipitate due to a rapid drop in $\mathrm{CO}_{2}$ partial pressure, a rise in ambient temperature and an increase in oxidation potential. Infrared spectra confirm that muds are mainly composed of goethite; however, other peaks, probably corresponding to carbonate, phosphate and nitrate groups have also been identified.

Chemical XRF analyses show that the muds are mainly composed of $\mathrm{Fe}_{2} \mathrm{O}_{3}$ ( $\sim 65$ wt.\%), with smaller proportions of
$\mathrm{SiO}_{2}$ ( \pm 3.86 wt.\%) and $\mathrm{P}_{2} \mathrm{O}_{5}( \pm 3.78$ wt.\%; Table 4). The high LOI observed are probably related to hydroxide and carbonate groups. Trace element analyses show relatively high content of $\mathrm{Ba}, \mathrm{Ce}, \mathrm{Zr}, \mathrm{Cu}$ and $\mathrm{Zn}$ (with some Sr, V, Co, Y; Table 4; Fig. 12), but no correlations have been established between the geochemical composition of ferruginous muds and the hydrochemical composition of the waters. This suggests that the composition of muds is not directly related to the initial composition of groundwaters. The high zirconium contents observed in muds certainly result from the gradual leaching of zircon releasing small amounts of uranium at the same time. RUY sample shows the highest radon activity and also the highest zirconium content (1843 ppm). There is a potential relationship between the zirconium content and the uranium content in muds although the radon activity does not appear to effectively correlate with the zirconium content in other samples.

Uranium and thorium have not been detected by XRF spectrometry in the mud samples (Table 4). This indicates that the $\mathrm{U}$ and Th contents are relatively low. An elementary EDX mapping has made it possible to detect some tiny spots of uranium, which do not seem correlated with other elements. The most likely hypothesis is that uranium is adsorbed in small concentrations on goethite surface. Indeed, goethite is 


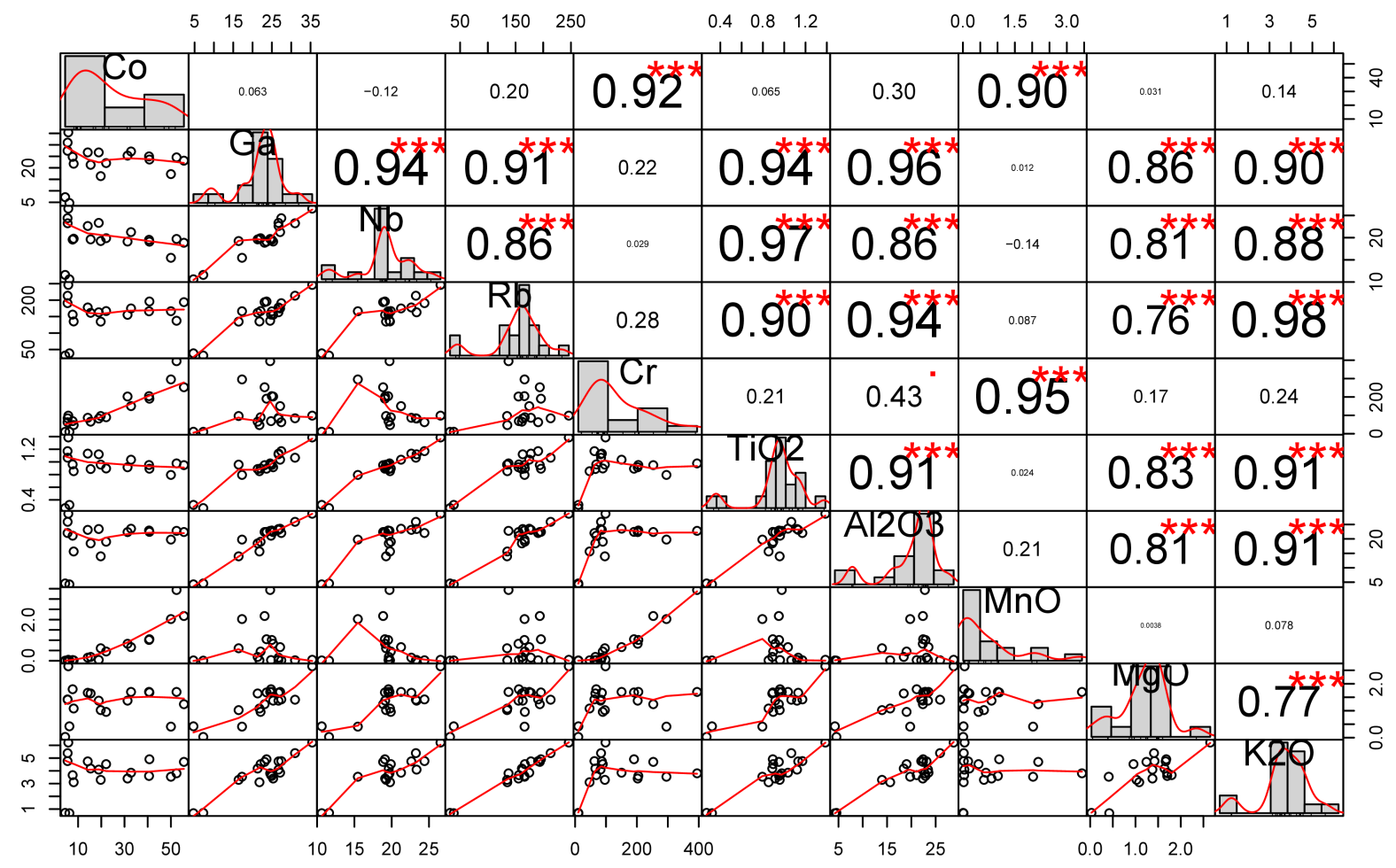

Figure 10. Correlation matrix between some major and trace elements.

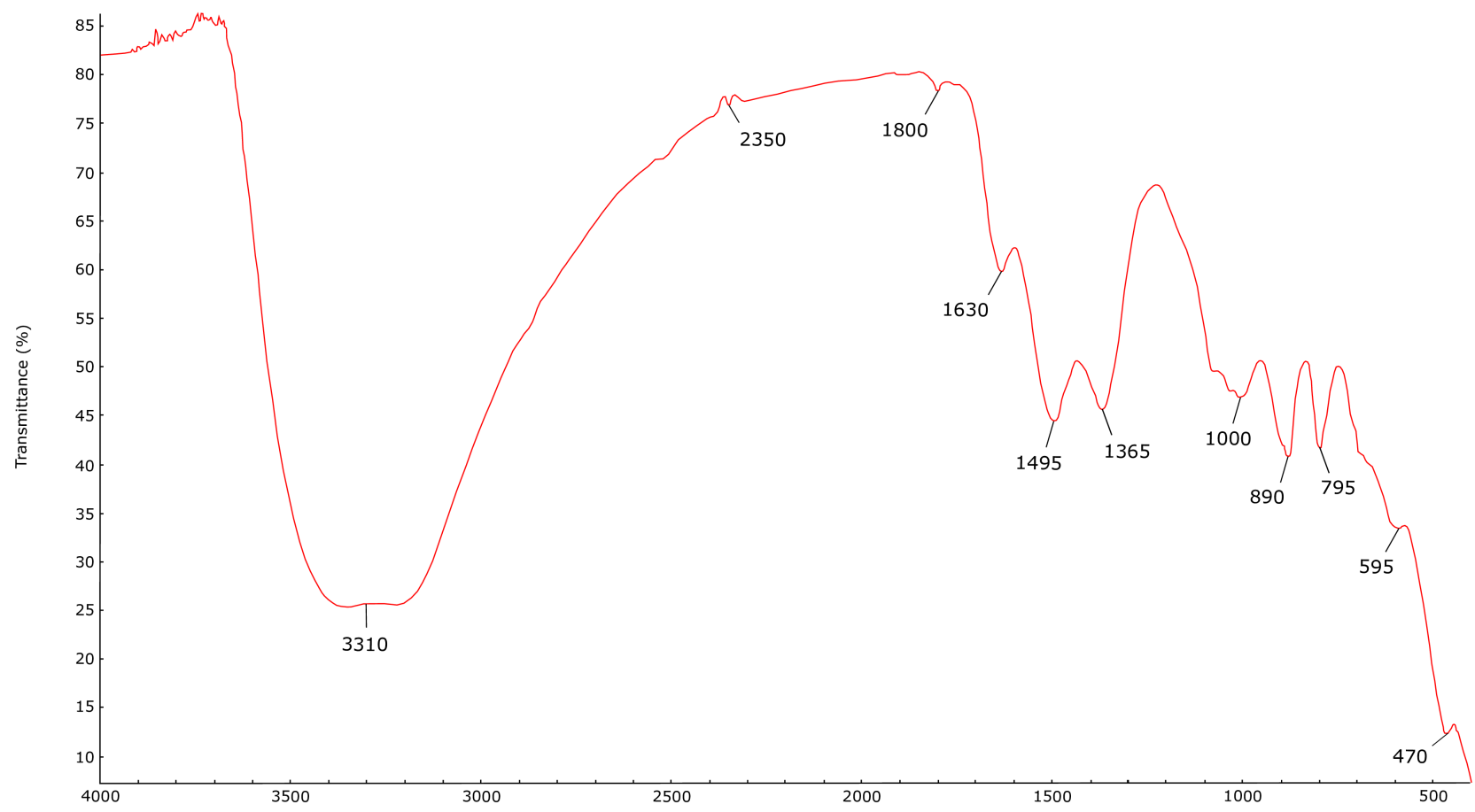

Figure 11. Infrared spectrum of a ferruginous mud sample (RUY).

characterised by a surface charge and has a high adsorption capacity for dissolved uranium (Hsi \& Langmuir, 1985). These authors demonstrated that the speciation of uranium in solution (dependent on $\mathrm{pH}$ ) significantly controls its degree of adsorption. The adsorption of $\mathrm{U}^{6+}$ is optimal in a $\mathrm{pH}$ range between 5 and 8.5 .

\subsection{Hydrochemistry of pouhon waters}

Pouhon waters are characterised by a particular hydrochemical composition. They are significantly enriched in iron and manganese and have frequently abnormally high lithium concentrations. In the same way, the Ottre Formation is enriched in $\mathrm{Fe}_{2} \mathrm{O}_{3}$ and $\mathrm{MnO}$ compared to other formations of the SVM. Dekoninck et al. (2019) carried out geochemical analyses on slates of the Ottré Formation. Data indicate that these rocks are also relatively rich in lithium with contents ranging from 50 to $328 \mathrm{ppm}$. Lithiophorite $\left((\mathrm{Al}, \mathrm{Li}) \mathrm{MnO}_{2}(\mathrm{OH})_{2}\right)$ is a weathering mineral abundantly found in this formation (Fransolet, 1979). The absence of this mineral in the other formations of SVM shows that lithium is mainly concentrated in the slates of the Ottré Formation. 


\begin{tabular}{|c|c|c|c|c|c|c|c|}
\hline Samples & BAR & RUY & PIA & PLG & GER & PIL & SAUV \\
\hline $\mathrm{SiO}_{2}$ & 2.51 & 3.08 & 5.94 & 3.89 & 59.99 & 27.16 & 63.82 \\
\hline $\mathrm{TiO}_{2}$ & ND & 0.02 & 0.08 & ND & 0.23 & 0.11 & 0.41 \\
\hline $\mathrm{Al}_{2} \mathrm{O}_{3}$ & 0.21 & 0.41 & 0.89 & 0.26 & 3.10 & 2.42 & 5.13 \\
\hline $\mathrm{Fe}_{2} \mathrm{O}_{3}$ & 64.03 & 63.88 & 66.50 & 64.15 & 20.07 & 34.74 & 12.26 \\
\hline $\mathrm{MnO}$ & 0.03 & 0.03 & 0.02 & 0.07 & 0.07 & 0.09 & 0.03 \\
\hline $\mathrm{MgO}$ & 0.53 & 0.63 & 0.59 & 0.60 & 0.94 & 0.65 & 0.33 \\
\hline $\mathrm{CaO}$ & 0.20 & 2.02 & 0.33 & 1.14 & 2.24 & 4.65 & 1.37 \\
\hline $\mathrm{Na}_{2} \mathrm{O}$ & ND & 0.04 & ND & ND & 0.09 & 0.20 & 0.25 \\
\hline $\mathrm{K}_{2} \mathrm{O}$ & 0.02 & 0.07 & 0.12 & 0.02 & 0.59 & 0.59 & 0.85 \\
\hline $\mathrm{P}_{2} \mathrm{O}_{5}$ & 5.54 & 3.00 & 1.69 & 4.90 & 0.81 & 0.06 & 0.67 \\
\hline LOI & 28.95 & 27.49 & 25.81 & 27.10 & 12.15 & 30.74 & 11.18 \\
\hline Tot & 102.03 & 100.67 & 101.99 & 102.12 & 100.29 & 101.42 & 96.30 \\
\hline Co & 19 & 17 & 18 & 20 & 14 & 33 & 8 \\
\hline $\mathrm{Cu}$ & 41 & 20 & 37 & 32 & 313 & 122 & 89 \\
\hline $\mathrm{Ga}$ & ND & ND & ND & ND & ND & ND & 4 \\
\hline $\mathrm{Nb}$ & ND & ND & ND & ND & 7 & 2 & 11 \\
\hline $\mathrm{Ni}$ & 3 & 4 & 1 & 2 & 10 & 13 & 10 \\
\hline $\mathrm{Pb}$ & 4 & ND & ND & ND & 29 & 16 & 218 \\
\hline $\mathrm{Rb}$ & 5 & 7 & 8 & 5 & 28 & 26 & 41 \\
\hline $\mathrm{Sr}$ & 27 & 154 & 29 & 108 & 65 & 102 & 66 \\
\hline Th & ND & ND & ND & ND & ND & ND & ND \\
\hline U & ND & ND & ND & ND & ND & ND & ND \\
\hline$Y$ & 10 & 10 & 21 & 15 & 21 & 72 & 21 \\
\hline $\mathrm{Zn}$ & 847 & 52 & ND & ND & 220 & 64 & 231 \\
\hline $\mathrm{Zr}$ & 18 & 1843 & 149 & 41 & 166 & 152 & 275 \\
\hline $\mathrm{Ba}$ & 23 & 240 & 0 & 275 & 287 & 301 & 412 \\
\hline $\mathrm{Ce}$ & 143 & 45 & 52 & 94 & 208 & 24 & 284 \\
\hline $\mathrm{Cr}$ & 1 & ND & ND & 2 & 6 & 13 & 5 \\
\hline V & 4 & 4 & 22 & ND & 43 & 32 & 45 \\
\hline
\end{tabular}

Table 4. Major oxides (wt.\%) and trace elements (ppm) geochemical XRF analyses of ferruginous mud samples. LOI = Loss on ignition; ND $=$ not detected.

Figure 12. Trace element contents (ppm) in ferruginous muds.

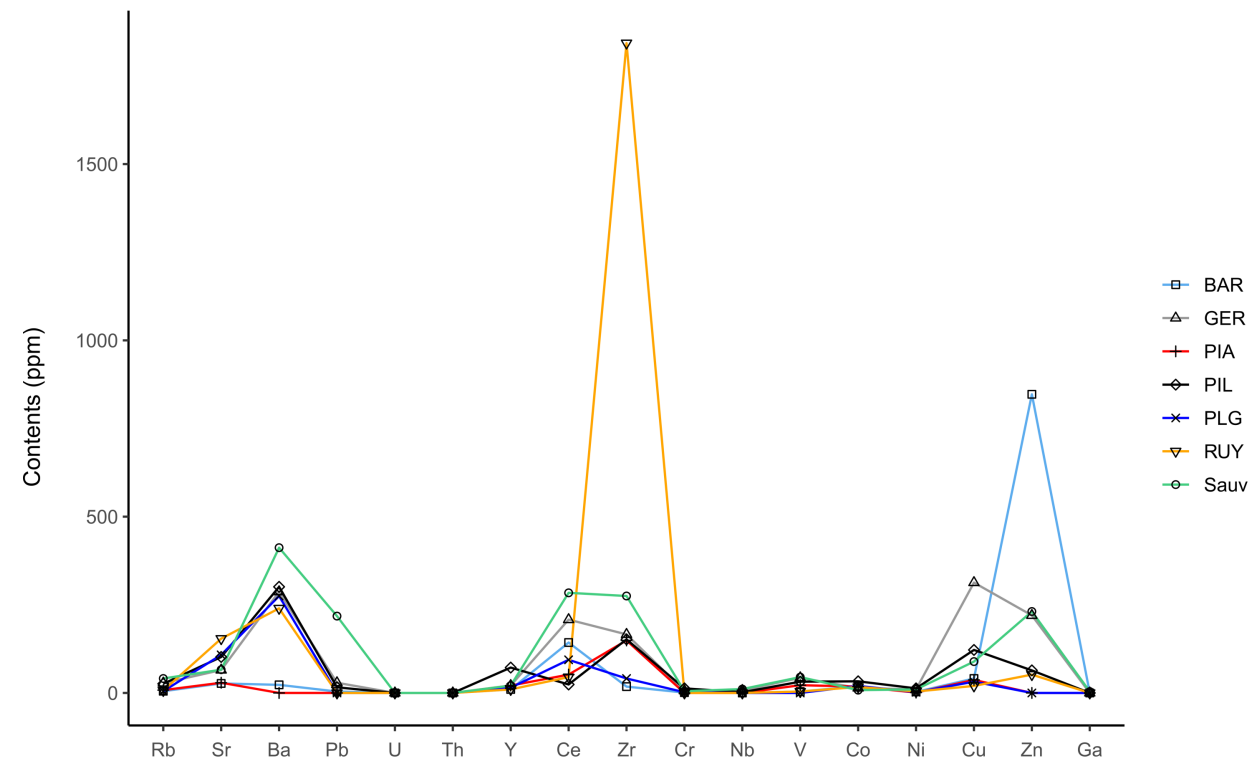

Although the composition of groundwaters appears to be closely related to the slates of the Ottré Formation, the extent of these rocks is relatively limited and pouhons are mainly located in rocks of the Revin Group. Waters have therefore interacted and potentially leached these rocks during their upwelling. The black shales of the La Gleize Formation appear to be the main source of uranium at the origin of radon activity observed in ferruginous muds. Moreover, the loss of uranium in the alteration products (Spox) compared to the protolith demonstrate the relatively high mobility of this element during weathering processes. These results suggest that the naturally $\mathrm{CO}_{2}$-rich waters occurring in the pouhons of the SVM have probably leached rocks of various mineralogy and chemical composition during their circulation in the sub-surface.

\section{Acknowledgements}

The authors thank N. Delmelle, who performed the XRF analyses, as well as J. Vander Auwera who gave access to the XRF instrument. Many thanks are due to S. Philippo for the 
access to the scanning electron microscope and his help during measurements. The authors would like to thank Spadel for giving access to data, and M. Blondieau and S. Puccio for their help during samples collection. Finally, the authors thank Martin Salamon and an anonymous reviewer who helped to improve the quality of this paper.

\section{References}

Baijot, M., Hatert, F. \& Fransolet, A.-M., 2011. Mineralogical and geochemical study of pseudocoticule from the Stavelot Massif, Ardennes (Belgium), and redefinition of coticule. European Journal of Mineralogy, 23, 633-644. https://doi.org/10.1127/09351221/2011/0023-2115

Barros, R., Defourny, A., Collignon, A, Jobé, P., Dassargues, A., Piessens, K. \& Welkenhuysen, K., 2021. A review of the geology and origin of $\mathrm{CO}_{2}$ in mineral water springs in east Belgium. Geologica Belgica, 24, 17-31. https://doi.org/10.20341/gb.2020.023

Blondieau, M., Puccio, S., Compère, P. \& Hatert, F., 2017. Données nouvelles sur quelques espèces minérales de Vielsalm et Salmchâteau (Province de Luxembourg, Belgique). Bulletin de la Société Royale des Sciences de Liège, 86, 1-48.

Bultynck, P. \& Dejonghe, L., 2001. Devonian lithostratigraphic units (Belgium). Geologica Belgica, 4/1-2, 39-69. https:// doi.org/10.20341/gb.2014.043

Burnotte, E., Pirard, E. \& Michel, G., 1989. Genesis of gray monazites: Evidence from the Paleozoic of Belgium. Economic Geology, 84, 1417-1429. https://doi.org/10.2113/gsecongeo.84.5.1417

Charlet, J.M., Dupuis, M. \& Quinif, Y., 1977. Perspectives de la prospection de l'uranium à l'échelle nationale. Annales des Mines de Belgique, 5, 521-531.

Charlet, J.M., Dejonghe, L., DeWitte, S.M., Drumel, B., Henry, J., Herbosch, A, Lefin, J.P. \& Martin, H., 1983. Reconnaissance survey for uranium in the Belgian Paleozoic. Professional Paper, Geological Survey of Belgium, 196, $189 \mathrm{p}$.

Cocks, L.R.M. \& Fortey, R.A., 2009. Avalonia: a long-lived terrane in the Lower Palaeozoic? Geological Society, London, Special Publications, 325, 141-155. https://doi.org/10.1144/SP325.7

Deer, W.A., Howie, R.A. \& Zussman, J., 1962. Rock-Forming Minerals. Vol.5, Non-silicates. London, Longmans, $371 \mathrm{p}$.

Defourny, A., Kremer, T., Collignon, A., Jobé, P., Nguyen, F. \& Dassargues, A., 2019. Integration of proxy data for a better comprehension of naturally sparkling mineral groundwater in the Stavelot massif (south-east of Belgium). In: GQ 2019: 10th International Groundwater Quality Conference, September 9-12, 2011, Liège, Belgium.

Defourny, A., Nguyen, F., Collignon, A., Jobé, P., Dassargues, A. \& Kremer, T., 2020. Induced polarization as a proxy for $\mathrm{CO}_{2}$-rich groundwater detection-Evidences from the Ardennes, South-East of Belgium. Water (Switzerland), 12/5, 1394. https:// doi.org/10.3390/w12051394

Dekoninck, A., Monié, P., Blockmans, S., Hatert, F., Rochez, G. \& Yans, J., 2019. Genesis and ${ }^{40} \mathrm{Ar} /{ }^{39} \mathrm{Ar}$ dating of K-Mn oxides from the Stavelot Massif (Ardenne, Belgium): Insights into Oligocene to Pliocene weathering periods in Western Europe. Ore Geology Reviews, 115, 103191. https://doi.org/10.1016/j.oregeorev.2019.103191

Dumont, A., 1852. Cristaux de chalcolite trouvés près de Vielsalm. Bulletins de l'Académie royale des Sciences, des Lettres et des Beaux-Arts de Belgique, 19, 343-344.

Ferket, H., Muchez, P., Schroyen, K. \& Sintubin, M., 1998. Metamorphism in the Stavelot-Venn Massif: A study of quartz veins in the basal Devonian conglomerates (Lochkovian). Aardkundige Mededelingen, 9, 7-16.

Fielitz, W. \& Mansy, J-L., 1999. Pre- and synorogenic burial metamorphism in the Ardenne and neighbouring areas (Rhenohercynian zone, central European Variscides). Tectonophysics, 309, 227-256. https://doi.org/10.1016/S0040-1951 (99)00141-9
Fransolet, A.-M., 1979. Occurrences de lithiophorite, nsutite et cryptomélane dans le Massif de Stavelot, Belgique. Annales de la Société géologique de Belgique, 102, 303-312.

Graham, J. \& Morris, R.C., 1973. Tungsten- and antimony-substituted rutile. Mineralogical Magazine, 39, 470-473. https:// doi.org/10.1180/minmag.1973.039.304.11

Geukens, F., 1986. Commentaire à la carte géologique du Massif de Stavelot. Aardkundige Mededelingen, 3, 15-30.

Geukens, F., 1999. Notes accompagnant une révision de la carte structurale du Massif de Stavelot. Aardkundige Mededelingen, 9, 183-190.

Griesshaber, E., O’Nions, R.K. \& Oxburgh, E.R., 1992. Helium and carbon isotope systematics in crustal fluids from the Eifel, the Rhine Graben and Black Forest, F.R.G. Chemical Geology, 99, 213-235. https://doi.org/10.1016/0009-2541(92)90178-8

Hatert, F., Deliens, M., Fransolet, A.-M. \& Van Der Meersche, E., 2002. Les Minéraux de Belgique. 2e éd.Institut royal des Sciences naturelles de Belgique, Bruxelles, $304 \mathrm{p}$.

Herbosch, A., Liégeois, J.-P. \& Pin, C., 2016. Coticules of the Belgian type area (Stavelot-Venn Massif): Limy turbidites within the nascent Rheic oceanic basin. Earth-Science Reviews, 159, 186-214. https://doi.org/10.1016/j.earscirev.2016.05.012

Herbosch, A., Liégeois, J.-P., Gärtner, A., Hofmann, M. \& Linnemann, U., 2020. The Stavelot-Venn Massif (Ardenne, Belgium), a rift shoulder basin ripped off the West African craton: Cartography, stratigraphy, sedimentology, new U-Pb on zircon ages, geochemistry and $\mathrm{Nd}$ isotopes evidence. Earth-Science Reviews, 203, 103142. https://doi.org/10.1016/j.earscirev.2020.103142

Hsi, C.D. \& Langmuir, D., 1985. Adsorption of uranyl onto ferric oxyhydroxides: Application of the surface complexation sitebinding model. Geochimica et Cosmochimica Acta, 49/9, 19311941. https://doi.org/10.1016/0016-7037(85)90088-2

IAEA/WMO, 2019. Global Network of Isotopes in Precipitation. The GNIP Database. https://www.iaea.org/services/networks/gnip, accessed 03/12/2019.

Jobé, P., 2014. Les eaux minérales et thermales en Wallonie. In Dassargues A. \& Walraevens K. (eds), Watervoerende Lagen en Grondwater in België / Aquifères et Eaux Souterraines en Belgique. Gent, Academia Press, 331-350.

Kodama, H., 1985. Infrared Spectra of Minerals. Reference Guide to Identification and Characterization of Minerals for the Study of Soils. Ottawa, Agriculture Canada Research Branch, 197 p.

Kramm, U., Spaeth, G. \& Wolf, M., 1985. Variscan metamorphism in the NE Stavelot-Venn, Ardennes: A new approach to the question of regional dynamothermal or contact metamorphism. Neues Jahrbuch für Geologie und Paläontologie, 171, 311-327.

Kretz, R., 1983. Symbols of rock-forming minerals. American Mineralogist, 68, 277-279.

Krosse, S. \& Schreyer, W., 1993. Comparative geochemistry of coticules (spessartine-quartzite) and their redschist country rocks in the Ordovician of the Ardennes Mountains, Belgium. Chemie der Erde, 53, 1-20.

Lamens, J. \& Geukens, F., 1984. Volcanic activity in the Lower Ordovician of the Stavelot Massif, Belgium. Koninklijke Academie voor Wetenschappen, 46, 1-13.

McLennan, S.M., 2001. Relationships between the trace element composition of sedimentary rocks and upper continental crust. Geochemistry, Geophysics, Geosystems, 2, 2000GC000109. https:// doi.org/10.1029/2000GC000109

Meis, C. \& Gale, J.D., 1998. Computational study of tetravalent uranium and plutonium lattice diffusion in zircon. Materials Science and Engineering, 57, 52-61. https://doi.org/10.1016/S09215107(98)00253-0

Mezger, K., Hanson, G.N. \& Bohlen, S.R., 1989. High-precision U-Pb ages of metamorphic rutiles: application to the cooling history of high-grade terranes. Earth and Planetary Science Letters, 96, 106118. https://doi.org/10.1016/0012-821X(89)90126-X 
Monjoie, A., 1995. Les eaux carbo-gazeuses et minéralisées du sud-est de la Belgique. La Houille Blanche, 2/3-1995, 100-105. https:// doi.org/10.1051/lhb/1995022

Rozanski, K., Araguás-Araguás, L. \& Gonfiantini, R., 1993. Isotopic patterns in modern global precipitation. In Swart, P.K., Lohmann, K.C., McKenzie, J. \& Savin, S. (eds), Climate Change in Continental Isotopic Records. American Geophysical Union, Washington, Geophysical Monograph, 78, 1-37. https:// doi.org/10.1029/GM078p0001

Schreyer, W., 1975. New petrologic evidence for Hercynian metamorphism in the Venn-Stavelot Massif, Belgium. Geologische Rundschau, 64, 819-830. https://doi.org/10.1007/BF01820698

Shannon, R.D., 1976. Revised effective ionic radii and systematic studies of interatomic distances in halides and chalcogenides. Acta Crystallographica, A32, 751-767. https://doi.org/10.1107/ S0567739476001551

Spaeth, G., Fielitz, W. \& Frank, B., 1985. Caledonian deformation and very low-grade metamorphism in the northeastern part of the Stavelot-Venn Massif. Neues Jahrbuch für Geologie und Paläontologie, Abhandlungen, 171, 297-310.

Taylor, H.P., 1974. The application of oxygen and hydrogen isotope studies to problems of hydrothermal alteration and ore deposition. Economic Geology, 69, 843-883. https://doi.org/10.2113/ gsecongeo.69.6.843

Torsvik, T.H., Van Der Voo, R., Preeden, U., Mac Niocaill, C., Steinberger, B., Doubrovine, P.V., Van Hinsbergen, D.J.J., Domeier, M., Gaina, C., Tohver, E., Meert, J.G., Mc Causland, P.J.A. \& Cocks, L.R.M., 2012. Phanerozoic polar wander, palaeogeography and dynamics. Earth-Science Reviews, 114, 325368. https://doi.org/10.1016/j.earscirev.2012.06.007

Vanderschueren, H.W., 2011. Le radon dans l'air, dans l'eau et dans les roches. Mesure dynamique de son exhalation et contribution à la caractérisation géologique des matériaux. Geological survey of Belgium professional paper, $308,96 \mathrm{p}$.

Vanderschueren, H.W., Goemare, E. \& Declercq, P.Y., 2007. Uranium et radon en Pays de Salm. In Goemaere, E. (ed.), Ardoise et Coticule en Terre de Salm. Bruxelles, Service géologique de Belgique, 336-353.

Verniers, J., Herbosch, A., Vanguestaine, M., Geukens, F., Delcambre, B., Pingot, J-L., Belanger, I., Hennebert, M, Debaker, T., Sintubin, M. \& De Vos, W., 2001. Cambrian-Ordovician-Silurian lithostratigraphic units (Belgium). Geologica Belgica, 4/1-2, 39-69. https://doi.org/10.20341/gb.2014.042

Vine, J.D. \& Tourtelot, E.B., 1970. Geochemistry of black shale deposits; a summary report. Economic Geology, 65, 253-272. https://doi.org/10.2113/gsecongeo.65.3.253

Whitney, D. \& Evans, B., 2010. Abbreviations for names of rockforming minerals. American Mineralogist, 95, 185-187. https:// doi.org/10.2138/am.2010.3371

Ziegler, A.M., Scotese, C.R., McKerrow, W.S., Johnson, M.E. \& Bambach, R.K., 1979. Paleozoic paleogeography. Annual Review of Earth and Planetary Sciences, 7, 473-502. https:// doi.org/10.1146/annurev.ea.07.050179.002353

Manuscript received 12.02.2021, accepted in revised form 28.04.2021, available online 29.10.2021. 